\title{
Relativization in Dàgáárè and its typological implications: Left-headed but internally-headed
}

\author{
Adams Bodomo ${ }^{\text {a }}$, Ken Hiraiwa ${ }^{b, *}$ \\ a Department of Linguistics, The University of Hong Kong, Pokfulam, Hong Kong \\ ${ }^{\mathrm{b}}$ Department of English Literature, Meiji Gakuin University, 1-2-37 Shirokanedai, Minato-ku, Tokyo, 108-8636, Japan
}

Received 22 August 2008; received in revised form 12 June 2009; accepted 19 June 2009

\begin{abstract}
This article examines in detail the syntax of relativization in Dàgáàrè, a Mabia (Oti-Volta) language of the Gur branch in the Niger-Congo family. The main aims of our investigation are twofold. The first is to describe a cluster of typologically interesting syntactic features of relativization in Dàgáárè in the light of the fact that no detailed description exists in the literature. The second is to demonstrate that relative clauses in Dàgáàrè are head-internal relative clauses (HIRCs), even though they are, on the surface, postnominal relative clauses, like those in English. Thus, they are not of the in-situ type of HIRC that is well known in the literature. We call this type of relative clause a left-headed HIRC. This type of relativization has rarely been noticed cross-linguistically in the previous literature and therefore is of considerable significance for general linguistics, linguistic typology, as well as theoretical linguistics. Evidence comes from coordination in possessor relativization and PP relativization. Our discovery shows that Universal Grammar allows left-headed HIRCs as an option in addition to the more familiar types: in-situ HIRCs and head-external relative clauses (HERCs).
\end{abstract}

(C) 2009 Elsevier B.V. All rights reserved.

Keywords: Head-internal relative clauses; Head-external relative clauses; Typology; Constituency; Pied-piping; Coordination; Gur

\section{Introduction: varieties of relative clauses}

The syntactic structure of relative clauses is an old but significant issue in linguistic theory. Chomsky (1977) proposed that relative clauses have an adjunction structure, as shown in the structure in (1a), (see also Jackendoff, 1972; Stockwell et al., 1973; Chomsky, 1977, 1995; Cinque, 1982; Lebeaux, 1990; Borsley, 1997; Sag, 1997, among

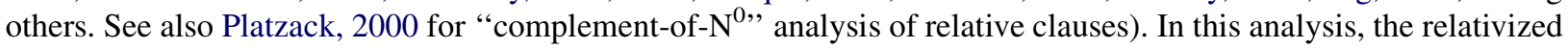
head noun is base-generated outside a relative clause and it is linked to the null operator that moves from the original position to [Spec, CP]. On the other hand, as shown in the structure in (1b), Vergnaud (1974) proposed that the relativized head of a relative clause raises from its original position to the left-peripheral position (see also Smith,

Abbreviations: Acc, accusative; C, complementizer; Comit, comitative; D, definite determiner; Dem, demonstrative determiner; Emph, emphatic; F, focus; Fut, future; Gen, genitive; Id, indefinite determiner; Imperf, imperfective; Loc, locative; Neg, negation; Nom, nominative; Perf, perfective; Pl, plural; Pst, past; Rel, relativizer; Sg, singular.

* Corresponding author.

E-mail addresses: abbodomo@hku.hk (A. Bodomo), hiraiwa@alum.mit.edu (K. Hiraiwa). 
1964; Brame, 1968; Schachter, 1973; Kayne, 1994; Bianchi, 2000; Aoun and Li, 2003; see Bianchi, 2002 for an overview of analyses of relative clauses in generative syntax).

a. Adjunction (Stockwell et al. 1973, Chomsky 1977)

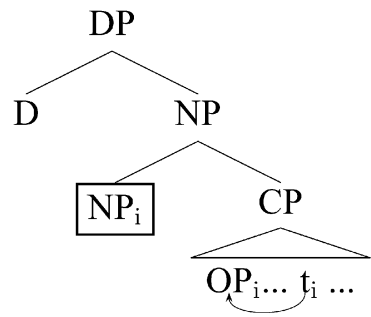

b. Raising (Vergnaud 1974, Kayne 1994)

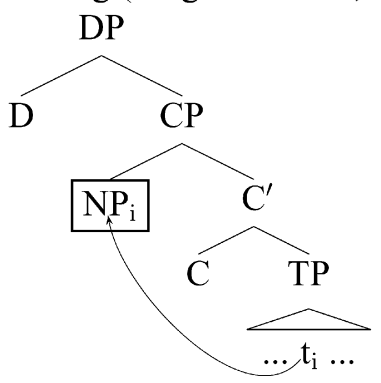

Kayne (1994) and others have proposed a raising analysis of relative clauses in English, roughly comparable to the one in (1b).

English relative clauses are, as is well known, postnominal - left-headed, in our terms introduced momentarily. Generally, they are considered to be externally-headed (hereafter head-external relative clauses (HERCs)). Historically, the term "postnominal relative clause" also often meant HERCs automatically. However, this is not quite precise in a more refined syntactic theory, because there are two analytical possibilities when a relativized head appears at the left-periphery: it can be external or internal to the CP clause. In this article, we use the terms head-external and head-internal purely in structural terms. A relative clause is head-external, if its relativized head noun appears outside the $\mathrm{CP}$ projection. A relative clause is head-internal, if its relativized head noun appears inside the relative clause (i.e. CP). Therefore, an externally-headed structure can be either generated by raising or base-generated. In contrast, the term postnominal or left-headed refers to the linear position of a relativized head noun. Thus, left-headed means postnominal as opposed to prenominal without any structural commitment. Thus, both analyses in (1) have been proposed for left-headed relative clauses in English, but the adjunction analysis (1a) argues for externally-headedness, whereas the raising analysis (1b) internallyheadedness.

Returning to Kayne's raising analysis (1b), the structure that he proposed is left-headed but internally-headed. However, Bhatt (2002) convincingly argues for a hybrid raising analysis for English, whose structure is diagramed as in (3). In this derivation, the relativized noun first undergoes an $\bar{A}$-movement ("raising") to [Spec, CP], from which it further moves and adjoins to $\mathrm{CP}$. Then, the relativized noun projects from there and it merges with the determiner. It is very important to notice that under his theory, English relative clauses are derived by raising but they are syntactically externally-headed with the head noun clearly outside CP (see also Iatridou et al., 2001; Cecchetto and Donati, 2008 for similar/related approaches). Hulsey and Sauerland (2006) reache yet another conclusion that English relative clauses are structurally ambiguous between head-external and head-internal structures.

(2) This is the book that John wrote. 
(3) Raising+Reprojection (Bhatt 2002)

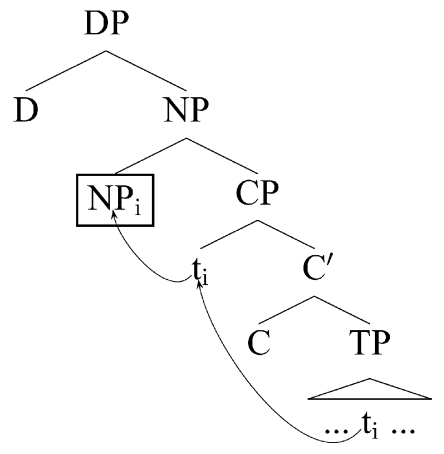

Typologically, it is well known that there is another type of relative clauses called head-internal relative clauses (HIRCs) (Cole, 1987; Williamson, 1987; Basilico, 1996; Watanabe, 2004, among others). It is called 'head-internal' because the relativized head noun remains in its original position as shown in (4) (some researchers propose a null operator movement, while others posit a null pronoun in the external head position, a choice of which is immaterial here).

(4)

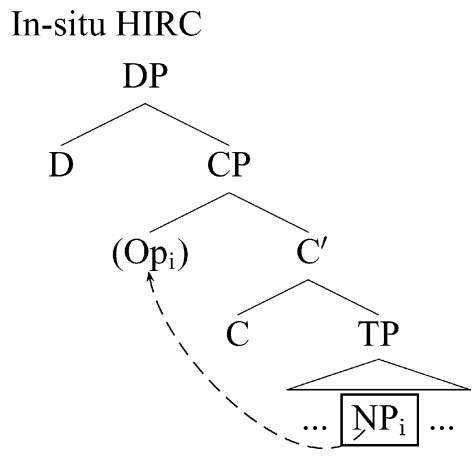

Basilico (1996), in his study on HIRCs, made an interesting and pertinent observation that in some languages, the relativized head noun at the left periphery is still located internally to the relative clause. The sentence (5a) is an example of an in-situ HIRC in Diegueño where the relativized head noun is wi:m 'with the rock' and appears in its original position. ${ }^{1}$ This relative clause has the structure in (4). In the example (5b), the head noun is moved to the left, leaving an obligatory resumptive pronoun in-situ. He argues that it is still located inside the relative clause, however. His evidence is based on the fact that in the example (5c), the relativized head noun is optionally moved leftward but it cannot receive the subject case-marker, which should be possible if the head noun were external to the clause. Instead, as shown in the grammatical example (5b), the relativized head noun must be zero-marked (i.e. marked with the object-marking). Thus, the case-marking shows that the fronted head noun is still internal to the relative clause, even though it appears at the left periphery. In other words, the example (5b) is an HIRC whose head noun does not remain in-situ. Let us call the relative clause in the example (5b) an ex-situ HIRC.

(5) The Mesa Grande dialect of Diegueño (Basilico 1996, 501, 505)
a. [xatcok $(-\phi)$ wi:m tuc-pu]-c $\mathrm{n}^{\mathrm{y}} \mathrm{iL}^{\mathrm{y}}$. dog-Obj rock-Comit I.hit-Dem-Subj black

'The rock that I hit the dog with was black.'

(In-situ HIRC)

b. ['wi ' ${ }^{\mathrm{y}}$ 'xat $(-\phi)$ ni $^{\mathrm{y}} \mathrm{i}-\mathrm{m} \quad$ Ptu:-pu]-c $\quad \mathrm{n}^{\mathrm{y}} \mathrm{iL}^{\mathrm{y}}$ cis. rock dog-Obj that-Comit I.hit-Dem-Subj black.indeed 'The rock that I hit the dog with was black.'

(Ex-situ HIRC)

\footnotetext{
${ }^{1}$ The sentence (5a) is actually ambiguous and the other interpretation is 'the dog that I hit with the rock was black'. However, the head-fronting in the relative clause $(5 b)$ disambiguates the sentence. 
c. *['wil ${ }^{\mathrm{y}}-$ pu-c 'xat- $\phi \quad$ ni ${ }^{\mathrm{y}} \mathrm{i}-\mathrm{m} \quad$ 'tu:-pu]-c $\quad \mathrm{n}^{\mathrm{y}} \mathrm{iL}^{\mathrm{y}}$ cis. rock-Dem-Subj dog-Obj that-Comit I.hit-Dem-Subj black.indeed 'The rock that I hit the dog with was black.'

Basilico (1996) argues that the moved head noun in (5b) is adjoined to IP via scrambling. This is illustrated in the structure below. ${ }^{2}$ He assumes that the determiner takes a IP/TP clause, but I indicate a CP as well (a head parameter is irrelevant in the following schematic structure).

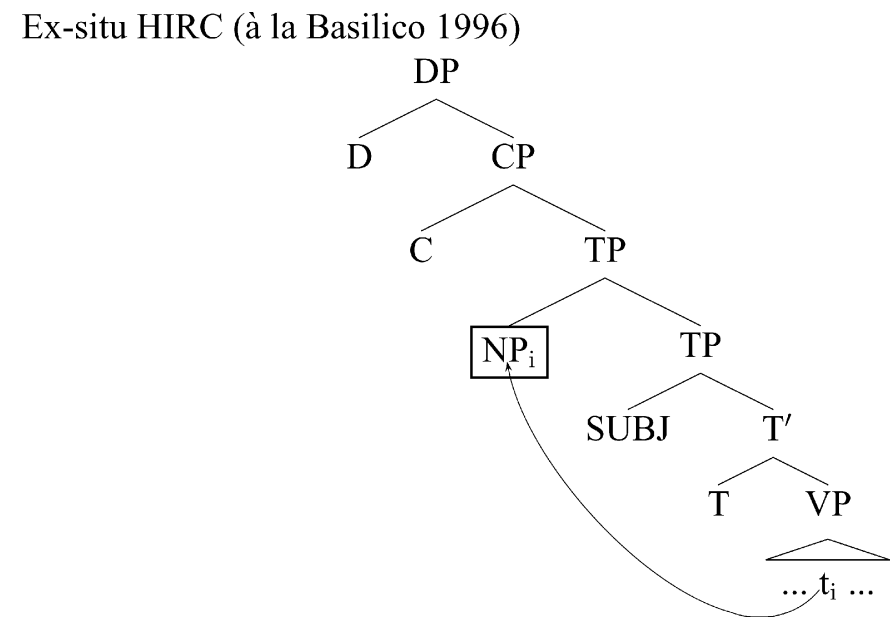

In this article, we will argue that relative clauses in Dàgáárè are also ex-situ HIRCs. However, we will demonstrate two significant properties: (i) the movement of the head in Dàgáárè is obligatory (unlike Diegueño) and (ii) the head noun lands in the left-edge position, higher than TP-i.e. the edge of CP. This is shown in the structure (7). Thus, we will call the relative clause of this type left-headed HIRCs. Notice that the relativized head noun phrase, even though it appears at the left periphery, is still internal to the CP clause. In other words, left-headed HIRCs are a subtype of ex-situ HIRCs in that the head noun is displaced, but they crucially differ in its landing site - TP vs. CP.

\section{Left-headed HIRC}

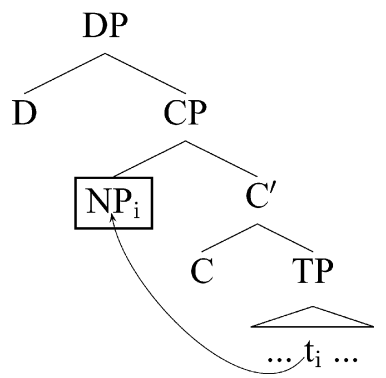

It should be emphasized that it is typologically significant to bring to light the existence of (7) in Dàgáárè, because such data bridge a gap in the typology of HIRCs. One of the main aims of parametric syntax and typology is to uncover principles that define possible languages (see Baker, 2001). Typological studies in the past decades have discovered languages that allow only in-situ HIRCs (e.g. Lakhota, Navajo) as well as languages that allow both in-situ and leftheaded HIRCs (e.g. Diegueño, Mojave, Japanese). The obvious missing paradigm is languages that only allow leftheaded HIRCs. This type of language is indeed expected to exist if no other principles block the option. This is the gap that Dàgáárè fills in.

\footnotetext{
${ }^{2}$ However, strictly speaking, he does not show evidence that it is adjoined to IP, not, for example, CP.
} 
Although movement of an internal head has been described in some detail before by Basilico (1996) and he analyzes it as optional scrambling, the obligatory left-fronted positioning of the head in Dàgáà is typologically not known yet. It should be noted that the left-headed HIRC pattern has also been observed in Yavapai (a Yuman language) by Kendall (1976), which was taken over in Lehmann (1984). Lehmann, however, judges the source as unreliable and no further investigation has been carried out. ${ }^{3}$ Therefore, confirmation of left-headed HIRCs with data from Dàgáárè (a language unrelated to Native American languages) is of much typological significance.

A word of caution is in order here. The structure of left-headed HIRCs (7) is essentially quite similar to Kayne's structure (1b). This might be a little confusing at first, since Kayne proposed the structure for English, whose relative clauses are assumed to be "externally-headed". But as we have explained above, theoretically, the relative clause (1b) is indeed internally-headed (putting aside whether English has this structure or not). In this article, we assume the explicit syntactic criterion: the crucial structural difference between HIRCs and HERCs is that in the former, the external D takes a CP as its complement, whereas in the latter, it takes an NP as its complement. From this criterion, the structures (1b), (4), (6) and (7) are all internally-headed, while the structures (1a) and (3) are externally-headed. ${ }^{4}$

The main aim of this article is to demonstrate that relative clauses in Dàgáárè are always left-headed, but still internally-headed, as those in Diegueño and Mojave are. However, Dàgáárè does not have subject-predicate agreement in most cases. Case-marking is also absent, unlike in Diegueño and Mojave. Thus, we will provide two pieces of novel evidence for left-headed HIRCs - PP relativization and possessor relativization and their interactions with coordination.

One of the crucial examples that we will focus on in this article is the following pairs of sentences in (8). In the example (8a), the complement noun of the $\mathrm{P}$ (ostposition) is relativized and appears at the left edge. In contrast, in the example (8b), the whole PP is pied-piped to the left edge. Building on coordination data, we will demonstrate that if relative clauses in Dàgáárè are externally-headed and have the adjunction structure (1a), relevant data become mysterious.

\section{(8) Relativization and pied-piping of $\mathrm{P}$}

a. ̀̀ dà dá lá à [lóórè nă $]_{i}$ Dàkóráá náng gâng $\grave{o}_{\mathrm{i}}$ póó.

1Sg Pst buy.Perf F D car Dem Dàkóráá C lie.Perf 3Sg in

'I bought the car in which Dàkóráá slept.' '*I bought the inside of the car in which Dàkóráá slept.'

b. ǹ dà dá lá à [lóórè nă póó] $]_{i}$ Dàkóráá náng gâng $\mathrm{t}_{\mathrm{i}}$.

1Sg Pst buy.Perf F D car Dem in Dàkóráá C lie.Perf

'I bought the car in which Dàkóráa slept.' 'I bought the inside of the car in

which Dàkóráá slept.'

The organization of this article is as follows: Section 2 describes significant features of relativization in Dàgáárè, to lay ground for main discussions. Section 3 investigates the syntactic structures of two types of Dàgáárè relativization PP relativization and possessor relativization - in relation to coordination, and argues that Dàgáàè relative clauses belong to what is called a left-headed HIRC in Hiraiwa $(2005,2008)$. Section 4 discusses typological implications. Section 5 concludes the article.

\section{Elements of Dàgáárè relativization}

Dàgáárè is a Mabia (Oti-Volta) language of the Gur branch of the Niger-Congo family and is spoken in the UpperWest region of Ghana. The language is spoken by approximately two million people. In this article, we will focus on the Jirapa dialect of Dàgáárè, the major dialect, which is also known as the Central dialect. Most readers and books for schools are written in this dialect, and the so-called standard Dàgáárè is based on it. The syntax and semantics of Dàgáárè relativization has been little described except for brief discussions in Bodomo (1997, 2000). Therefore, we

\footnotetext{
${ }^{3}$ He warns in a footnote (p. 121) that the pattern could be an idiolectal property of an informant whose speech is influenced by English or Spanish, and states that Yavapai is the only known language so far with this property. We are grateful to an anonymous reviewer for bringing our attention to this fact.

${ }^{4}$ Recall that Kayne's "head-internal" structure (1b) is refuted for English relative clauses by Bhatt (2002) in favor of the "head-external" structure (3) after all. It is not our aim in this article to examine the syntactic structures of English relative clauses. See Hulsey and Sauerland (2006) for more discussions.
} 
aim to reveal the workings of relativization in Dàgáárè. In so doing, it will become clear that Dàgáárè relativization has much to contribute to general linguistics and theoretical linguistics. In particular, this article shows that Dàgáárè has left-headed HIRCs, which are typologically almost unnoticed. Furthermore, our data show that a language can have left-headed HIRCs even though it does not allow in-situ HIRCs (or at least it allows very marginal in-situ HIRCs), in contrast with a language like Diegueño.

In this section, we will take a closer look at syntactic features of Dàgáárè relativization. The first section focuses on the exterior syntax such as determiners, and the second section examines the interior syntax with special focus on preverbal particles, $\mathrm{C}$ and the subject position.

\subsection{The exteriors}

As the declarative sentence (9a) shows, Dàgáárè is an SVO language with no null pronouns or overt agreement. It does not have scrambling and the word order can only be changed via $\bar{A}$-movement ( $W h$-movement, focus-movement, or topicalization). Bodomo (1997, 2000) and Dakubu (2005) present detailed overviews of aspects of the grammar of Dàgáárè. Many declarative root sentences have the postverbal declarative focus particle lá, behaviors of which are extremely complicated (see Dakubu, 1992; Bodomo, 1997, 2000; Hiraiwa and Bodomo, 2008 for some discussions). Dàgáárè is an obligatory $W h$-fronting language as shown in the Wh-Question (9b). Dislocated Wh-phrases are followed by the focus particle and the complementizer $\mathrm{ka}^{5}$

(9) Declarative and $W h$-question sentences
a. ̀̀ dá lá à gánè.
$1 \mathrm{Sg}$ buy.Perf F D book
'I bought the book.'

b. bòng lá ká fó dà?

what F C 2Sg buy.Perf

'What did you buy?'

Now let us examine relative clauses in (10) in detail.

a. Subject relativization

ǹ nyé lá à pógó $_{\mathrm{i}}$ ná $e_{\mathrm{i}} /$ * $_{\mathrm{i}}$ náng nòng Dàkóráá.

$1 \mathrm{Sg}$ see F D woman Dem $\phi / 3 \mathrm{Sg} C$ like Dakoraa

'I saw the woman who likes Dakoraa.'

b. Object relativization

ǹ nyé lá à pógó $\dot{\mathrm{i}}_{\mathrm{i}}$ ná Dàkóráá náng nòng $e_{\mathrm{i}} / *_{\mathrm{o}_{\mathrm{i}}}$. $1 \mathrm{Sg}$ see F D woman Dem Dakoraa C like $\phi / 3 \mathrm{Sg}$

'I saw the woman who Dakoraa likes.'

In Dàgáárè relativization, the head noun of the relative clause - indicated in boldface - comes in the initial (i.e. leftedge) position of the relative clause, just like $W h$-phrases. The relativized head noun takes the definite determiner $a$ and the distal demonstrative determiner ná. The deictic distal meaning of the latter, however, disappears in relativization, as in many other Gur /non-Gur languages, and this indicates that the demonstrative determiner in question has grammaticalized in some sense (cf. Kayne, 2008). In addition, the particle náng has to come before the verb. As we will show, this element is a complementizer. In Dàgáárè relativization, there is always a gap with a systematic exception for relativization of possessors or objects of postpositions, where a resumptive possessive pronoun is required as we will see later. Otherwise, if a resumptive pronoun is used in the examples below, they are ungrammatical.

In Dàgáárè, there seems to be no grammatical relational restriction on relativizable elements (see Keenan and Comrie, 1977). It is possible to relativize a possessor noun phrase in Dàgáárè. It is most natural to leave the possessee

\footnotetext{
${ }^{5}$ The complementizer $k a$ is obligatorily absent in root subject $W h$-questions.
} 
noun phrase in-situ with a resumptive possessive pronoun, but it is also grammatical to pied-pipe the entire noun phrase. $^{6,7}$

(11) Possessor relativization

a. ǹ dà nyé lá à [pógó ${ }_{i}$ ná] ̀̀ nàng sóré ò gánè dèyâng.

1Sg Pst see.Perf F D woman Dem 1Sg C read.Perf 3Sg book last.year

'I saw the woman whose book I read last year.'

b. ǹ dà nyé lá à [pógó ná gánè] $]_{\mathrm{i}}$ ̀̀ náng sóré $\mathrm{t}_{\mathrm{i}}$ dèyâng.

1Sg Pst see.Perf F D woman Dem book $1 \mathrm{Sg} \mathrm{C}$ read.Perf last.year

'I saw the woman whose book I read last year.'

Furthermore, it is also licit to relativize the object of postposition and the object of comparison in Dàgáárè.

(12) PP relativization

a. à [péé $\varepsilon_{\mathrm{i}}$ ná] Dàkóráá náng gâng $\grave{o}_{\mathrm{i}}$ zû é lá kpông.

$\mathrm{D}$ roof Dem Dàkóráá $\mathrm{C}$ lie.Perf $3 \mathrm{Sg}$ on be $\mathrm{F}$ big

'The roof top on which Dàkóráá lay is big.'

b. à [péé ${ }_{\mathrm{i}}$ ná zû̃ $]_{\mathrm{i}}$ Dàkóráá náng gâng $\mathrm{t}_{\mathrm{i}}$ é lá kpông.

$\mathrm{D}$ roof Dem on Dàkóráá $\mathrm{C}$ lie.Perf be $\mathrm{F}$ big

'The roof top on which Dàkóráá lay is big.'

(13) Comparative relativization

à [dóó ${ }_{i}$ ná] Dàkóráá náng è wógì gàngè $e_{\mathrm{i}}$ záà kpiè lá.

$\mathrm{D}$ man Dem Dàkóráá $\mathrm{C}$ be tall pass yesterday die $\mathrm{F}$

'The man who Dàkóráá is taller than died yesterday.'

The structure of the PP relativization and the possessor reltivization will be discussed in greater detail in Section 3.

Crucially, Dàgáárè does not allow in-situ HIRCs unlike some other Gur languages (Bùlì (Hiraiwa, 2005, 2008, in preparation), Mooré (Peterson, 1974; Tellier, 1989), Dagbani (Wilson, 1963)), where the relativized head noun can remain in its original position. Compare (10b) with (14). ${ }^{8}$

a. Object HIRC

*ǹ dà sóré lá à Dàkóráá náng ngmàà gánè dèyâng.

1Sg Pst read.Perf F D Dàkóráá C write.Perf book last.year

'I read the book that Dàkóráá wrote last year.'

b. Object HIRC

* dà sóré lá à Dàkóráá náng ngmàà gánè nă dèyâng.

1Sg Pst read.Perf F D Dàkóráá C write.Perf book Dem last.year

'I read the book that Dàkóráá wrote last year.'

\footnotetext{
${ }^{6}$ The use of resumptive pronouns in possessor relativization and PP relativization is fairly common in HIRCs in Gur languages. In addition, Bùlì uses a resumptive pronoun in long-distance relativization. Kabiyé uses resumption in subject positions. Also recall that ex-situ HIRCs discussed by Basilico (1996) employs resumption as well.

${ }^{7}$ This example has another interpretation 'I saw the woman's book that I read last year.' but we will ignore this interpretation as it is irrelevant to our discussions.

${ }^{8}$ As we mentioned in the beginning of this section, the dialect that we deal with in this article is the Jirapa dialect, the main dialect of Dàgáárè. In fact, another dialect seems to allow in-situ HIRCs marginally in certain cases. Because it has interesting differences in syntax and lexical items and also because we do not have sufficient data, we will leave an investigation of dialectal differences for future research.
} 
Because there is much parallelism between relative clauses and noun phrases cross-linguistically, let us examine the syntax of DP in some more detail. First, let us look at the placement of determiners. The element ná in Dàgáárè usually functions as a demonstrative determiner in Dàgáárè.

\section{Demonstrative $n a ́$}

ǹ dă lá à gánè nă.

1Sg buy.Perf F D book Dem

'I bought that book.'

The definite determiner $\grave{a}$ cannot basically be deleted (without changing the definiteness reading) when the DP appears without a relative clause, while the demonstrative ná can be omitted.

(16) Definite demonstrative omission

a. ̀̀ dă lá à gánè $\phi$.

1Sg buy.Perf F D book (Dem)

'I bought the book.'

\section{b. *ǹ dă lá $\phi$ gánè nă. \\ $1 \mathrm{Sg}$ buy.Perf F (D) book Dem \\ 'I bought that book.'}

One puzzle about the Dàgáárè DP structure is the fact that it is uniformly head-final except for the definite determiner à. Given the SVO word order of Dàgáárè, the head-final DP word order is presumably derived from movement. ${ }^{9}$ Specifically, we assume that the demonstrative head Dem has an EPP feature [+DP] that attracts the closest DP to its specifier, whereas the D head lacks such a feature. The derivation is represented as follows. The D lacks an EPP feature and hence nothing comes to its specifier. On the other hand, The Dem has an EPP feature and hence the entire DP moves to its specifier. As a result, the "D NP Dem" order obtains.
a. à gá-mà nă
D book-P1 Dem
'those books'

b. DP-structure

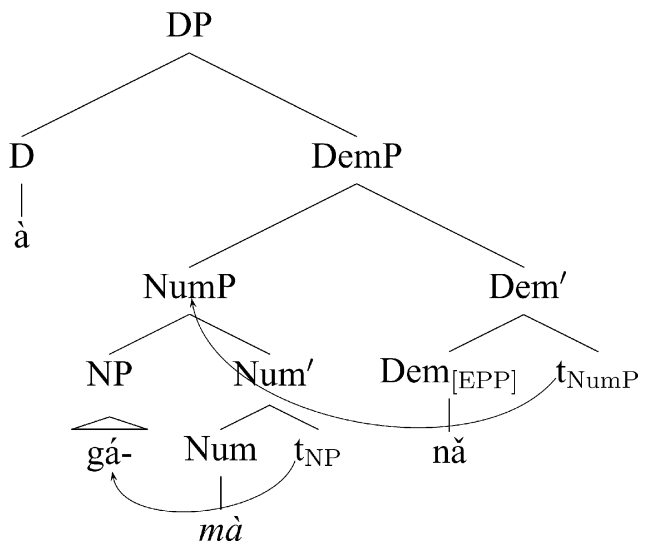

\footnotetext{
${ }^{9}$ As Matt Shibatani (p.c.) pointed out, there may have been some diachronic changes from one word order to the other. Unfortunately, there is no record of older stages of the language. 
In relative clauses, the demonstrative $n a$ is optional and its presence/absence does not affect a semantic interpretation. On the other hand, the complementizer náng is obligatory. Significantly, the definite determiner $\grave{a}$ can also be omitted, with the demonstrative ná retained. If both the demonstrative and the definite determiner are omitted, however, the sentence becomes ungrammatical as a definite relative clause; it can only be interpreted as an indefinite relative clause.

a. Subject relativization (Definite/Indefinite)

ǹ dà sóré lá à gánè nă / gánè nă / gánè *(náng) bìng kyê.

1Sg Pst read.Perf F D book Dem/book Dem/book C put here

'I read the/the/a book that is lying here.'

b. Object relativization (Definite/Indefinite)

ǹ dà sóré lá à gánè nă / gánè nă / gánè Dàkóráá *(náng)

1Sg Pst read.Perf F D book Dem / book Dem / book Dàkóráá C

ngmàà dèyâng.

write.Perf last.year

'I read the/the/a book that Dàkóráá wrote last year.'

Thus, the fact that the definite determiner is freely omitted in relative clauses but not in non-relative contexts suggests that the determiner $\grave{a}$ in relative clauses is located in a different position. We propose that it in fact takes a CP clause as a complement, as shown in (19) (see Kayne, 1994). ${ }^{10}$

a. $\mathrm{D}$ and relative clauses

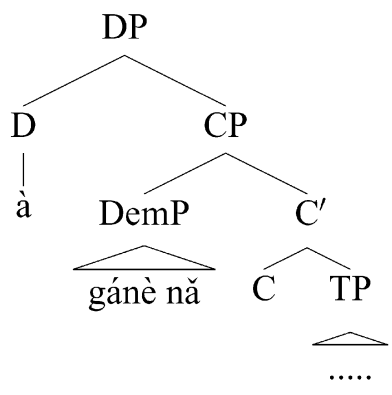

b. D and NP

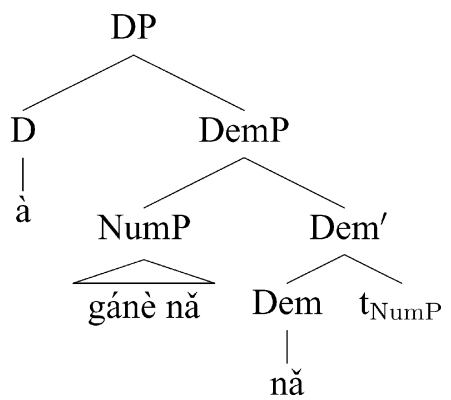

In other words, the determiner $a$ takes the DemP as its complement in noun phrases, but it takes the CP instead in relative clauess. ${ }^{11}$ In DPs, the demostrative ná clearly forms a constituent with the noun phrase, as shown by the clefting test below.

\footnotetext{
${ }^{10}$ Another construction in which a D takes a CP clause is a so-called Factive construction as shown in (i) (see Collins, 1994).
}

(i) Factive Construction

[à [Dàkóráá náng ngmàà à gánè dèyâng yélé]] pèlé lá ò póg(ó) póó yágà.

D Dàkóráá C write.Perf D book last.year Part. whiten.Perf F 3.Sg wife stomach a.lot

'The fact that Dàkóráá wrote a book last year pleased his wife a lot.'

${ }^{11}$ As we have observed, the omission of ná in relative clauses does not show any significant semantic difference - in particular, distal function. This leads us to think that the demonstrative determiner in relative clauses is syntactically and semantically bleached and grammaticalized into a definite determiner. We will, tentatively, assume that the demonstrative determiner ná is reanalyzed as a definite marker, losing its deictic function, when the NP functions as a relativized head in Dàgáàè. We leave for future research the investigation of the nature of the function of the demonstrative determiner in relative clauses in general. 
a. à móngó-rí ná

D mango-P1 Dem

'those mangoes'

b. à móngó-rí ná lá kà Dàkóráá dì zààmêng.

D mango-Pl Dem F C Dàkóráá eat.Perf yesterday

'It is the mangoes that Dàkóráá ate yestterday'

One might wonder if ná has grammaticalized into a complementizer in relative clauses, as that in English. There is good reason, however, to think that ná in relative clauses is a determiner not a complementizer. Consider the pair (21).

(21) Relativization and numerals

a. ̀̀ dà dí lá à móngó-rí ànúú ná Dàkóráá náng dà

1Sg Pst eat.Perf F D mango-Pl five Dem Dàkóráá C buy.Perf

zààmêng.

yesterday

'I ate the five mangoes that Dàkóráá bought yesterday.'

b. ̀̀ dà dí lá à móngó-rí ná ànúú Dàkóráá náng dà

1Sg Pst eat.Perf F D mango-P1 Dem five Dàkóráá C buy.Perf

zààmêng.

yesterday

'I ate the five mangoes that Dàkóráá bought yesterday.'

As the sentence (21b) shows, the numeral ànúú can come to the right of ná. This should be impossible if ná were a clausal functional head (like C(omplementizer)) as shown in (22). ${ }^{12}$

*ná as C (i.e. a clausal functional head)

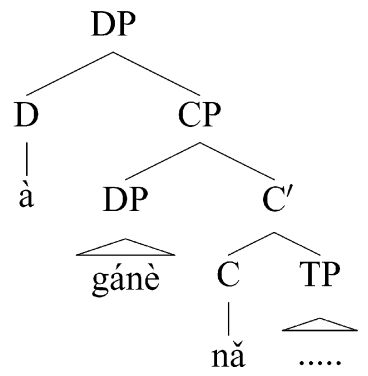

Similarly, when two modifying clauses are coordinated to modify the relativized head noun, ná cannot appear in the second conjunct. If ná were a complementizer, it would be expected to appear in both conjuncts. Compare the Dàgáàrè examples (24) with the English counterpart.

\footnotetext{
${ }^{12}$ When $\mathrm{P}$ is pied-piped with the relativized head noun, it must follow the demonstrative ná (if any); it cannot come before the demonstrative.

(i) The Placement of $\mathrm{P}$ and the demonstrative

*ǹ dà dá lá à lóórè póó ná [Dàkóráá náng gâng].

$1 \mathrm{Sg}$ Pst buy F D car in Dem Dàkóráá C lie.Perf

'I bought the car in which Dàkóráá slept.'

This confirms that the demonstrative ná is not a complementizer or a relative pronoun, but rather forms a constituent with the relativized head noun. See the detailed discussion in Section 3.
} 
(23) a. This is the article [that John wrote] and [that Mary reviewed].

b. This is the article [which John wrote] and [which Mary reviewed].

(24) Coordination of relative clauses and $n a ́$

a. ǹ òó lá à zómò ná Dàkóráá náng dà nyógè kà Déré dà 1 Sg eat.Perf F D fish Dem Dàkóráá C Pst catch.Perf Conj. Déré Pst dógé. cook.Perf

'I ate the fish that Dàkóráá caught and Déré cooked.'

b. *ǹ jó lá à zòmò ná Dàkóráá náng dà nyógè kà ná Déré 1Sg eat.Perf F D fish Dem Dàkóráá C Pst catch.Perf Conj. Dem Déré dà dógé.

Pst cook.Perf

'I ate the fish that Dàkóráá caught and Déré cooked.'

Finally, let us address a significant question of whether the relationship between the relativized head and the gap (or its resuptive pronoun) is mediated by movement or control or a kind of binding. As shown in the examples (25), the fact that relativization in Dàgáárè is subject to islands/subjacency suggests that the former is right. They show that relativization out of a complex NP or an adjunct clause is illicit in Dàgáárè. Note that island effects remain irrespective of the presence/absence of the resumptive pronouns.

a. Complex NP Constraint

* dà sóré lá à gánè nă [ǹ náng nyé [à pógó ná náng 1Sg Pst read.Perf F D book Dem 1Sg C see.Perf D woman Dem C ngmàà $\left.\left.\left(\grave{o}_{\mathrm{i}}\right)\right]\right]$. write.Perf (3Sg)

'I read the book that I saw the woman who wrote.'

b. Adjunct Island

* dà sóré lá à gánè nă [ǹ náng nyé [à pógó ò náng 1Sg Pst read.Perf F D book Dem 1Sg C see.Perf D woman 3Sg C ngmàà-rá $\left.\left.\left(\grave{o}_{\mathrm{i}}\right)\right]\right]$. write-Imperf (3Sg)

'I read the book that I saw the woman when she was writing it.'

\subsection{The interirors: complementizer and particles}

We now turn our attention to the interiors with particular focus on the preverbal particles observed in relative clauses and the position of the subject. We provide evidence that the particle náng is a complementizer. It cannot be omitted in Dàgáárè relativization and therefore is an indispensable syntactic ingredient.

\subsubsection{Preverbal particles}

Dàgáárè has a rich inventory of preverbal Tense-Aspect-Mood particles (see Bodomo, 1997). The preverbal particle nang has other uses in the grammatical system of Dàgáárè. Outside relative clauses, one of its clearest uses is as a preverbal particle that means 'still'. Note, however, that the tone is low in this use.

(26) A preverbal particle nàng

à dóó nàng nyúúró lá à kòó.

D man still drink.Imp F D water

'The man is still drinking the water.' 
In relativization, on the other hand, it is marked with a high tone.

(27) náng in a relative clause

ǹ dà sóré lá à gánè ná [Dàkóráá náng ngmàà dèyâng]. 1Sg Pst read.Perf F D book Dem Dàkóráá C write.Perf last.year

'I read the book that Dàkóráá wrote last year.'

The high-tone complementizer náng is also used in temporal adverbial clauses.

(28) náng in a temporal clause

[à dóó náng wà tá], ì dé lá gánè kò ó.

$\mathrm{D}$ man when come.Perf reach.Perf $1 \mathrm{Sg}$ take.Perf $\mathrm{F}$ book give $3 \mathrm{Sg}$

'When the man arrived I gave him a book.'

Despite the morphological identity, these particles are distinct syntactic heads. The complementizer náng can in fact co-occur with the preverbal particle nàng. Furthermore, it can also co-occur with other preverbal particles such as the past tense particles $d a$ and zaa. Crucially, the complementizer náng precedes all of those so-called preverbal particles.

(29) Preverbal particle nàng and complementizer náng

ǹ nyé lá à gánè nă [Dàkóráá náng nàng ngmàà-rá].

1Sg see.Perf F D book Dem Dàkóráá C still write-Imperf

'I saw the book that Dàkóráá is still writing.'

(30) a. Object relativization (Past)

ǹ dà sóré lá à gánè nă Dàkóráá (*dà) náng (dà) ngmàà

1Sg Pst read.Perf F D book Dem Dàkóráá (Pst) C (Pst) write.Perf

dèyâng.

last.year

'I read the book that Dàkóráá wrote last year.'

b. Object relativization (Past)

ǹ dà sóré lá à gánè nă Dàkóráá ("záà) náng (záà) ngmàà.

1Sg Pst read.Perf F D book Dem Dàkóráá (Pst) C $\quad$ (Pst) write.Perf

'I read the book that Dàkóráá wrote yesterday.'

Whereas the relativizing particle náng must precede the tense and all the other particles, the preverbal particle nàng must follow the tense particle.

a. ò dà nàng bá wà sćré.

3Sg Pst still Neg come yet

'He hadn't come yet.'

b. ǹ nyé lá à gánè nǎ Dàkóráá náng dà nàng ngmàà-rà.

1Sg see.Perf F D book Dem Dàkóráá C Pst still write-Imperf

'I saw the book that Dàkóráá was still writing.' 
The future particle nà also follows the complementizer náng, as shown below.

(32) Object relativization (Future)

ǹ dà nyé lá à gánè ná Dàkóráá (*nà) náng (nà) kó má biéú.

I Pst see.Perf F D book Dem Dàkóráá (Fut) C (Fut) give me tomorrow

'I saw the book that Dàkóráá will give me tomorrow.'

It is worth noting that the fact that these tense particles can occur within the relative clauses in Dàgáárè indicates that the relative clauses are fully finite (and hence not "reduced" in any sense). ${ }^{13}$ The co-occurrence and word order facts demonstrate that the relativizing particle náng is a complementizer.

(33) The hierarchical structure of particles

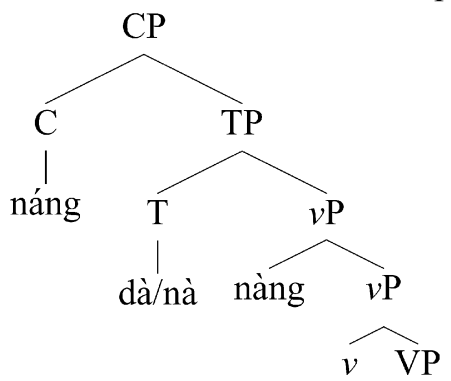

\subsection{2. $C$, subject, and verb}

As the examples in (34) show, the time adverb in Dàgáárè can be placed at the right edge of the clause (34a), or at the left-edge of the clause (34b), but not in the medial positions (34c)-(34e). In either case, the natural assumption is that the former is adjoined to TP and the latter is topicalized. The grammatical example (34f) indicates that the temporal adverb can also incorporate into $\mathrm{T}$.
a. Dàkóráá dà ngmàá lá à gánè dèyâng.
Dàkóráá Pst write.Perf F D book last.year
'Dàkóráá wrote the book last year.'

b. dèyâng Dàkóráá dà ngmàá lá à gánè. last.year Dàkóráá Pst write.Perf F D book

c. *Dàkóráá dà ngmàá lá dèyâng à gánè. Dàkóráá Pst write.Perf F last.year D book

d. *Dàkóráá dà ngmàà dèyâng lá à gánè. Dàkóráá Pst write.Perf last.year F D book

e. *Dàkóráá dà dèyâng ngmàá lá à gánè. Dàkóráá Pst last.year write.Perf F D book

f. Dàkóráá dèyâng dà ngmàá lá à gánè. Dàkóráá last.year Pst write.Perf F D book

Now let us examine adverb placement in relative clauses. An embedded adverb cannot come before the complementizer (35c). It cannot be placed before the demonstrative ná (35d) or just after it (35e). Neither can

\footnotetext{
${ }^{13}$ The particle náng does not have any use as a complementizer in Wh-questions and focus constructions. In these constructions, the complementizer $k a$ is used (see (9b) and (20b)). It should be noted that there is no construction where ka and náng co-occur, which supports our conclusion that náng is a complementizer, rather than a Tense-Aspect-Mood particle.
} 
the adverb precede the relativized head noun (35f). Thus the well-formed adverb placement is either between the complementizer náng and the verb (35b) or at the end of the relative clause (35a).

The fact that the adverb cannot precede náng shows that the latter is located higher than T. Therefore it confirms our conclusion that it is $\mathrm{C}$.

(35) Adverb placement in Dàgáárè relativization

a. ǹ dà sóré lá [à gánè ná Dàkóráá náng dà ngmàà dèyâng].

1Sg Pst read.Perf F D book Dem Dàkóráá C Pst write.Perf last.year

b. ̀̀ dà sóré lá [à gánè ná Dàkóráá náng dèyâng dà ngmàà].

1Sg Pst read.Perf F D book Dem Dàkóráá C last.year Pst write.Perf

c. *ǹ dà sóré lá [à gánè ná Dàkóráá dèyâng náng dà ngmàà].

1Sg Pst read.Perf F D book Dem Dàkóráá last.year C Pst write.Perf

d. *ǹ dà sóré lá [à gánè dèyâng ná Dàkóráá náng dà ngmàà].

1Sg Pst read.Perf F D book last.year Dem Dàkóráá C Pst write.Perf

e. *ǹ dà sóré lá [à gánè ná dèyâng Dàkóráá náng dà ngmàà].

1Sg Pst read.Perf F D book Dem last.year Dàkóráá C Pst write.Perf

f. *ǹ dà sóré lá [dèyâng à gánè ná Dàkóráá náng dà ngmàà].

1Sg Pst read.Perf F last.year D book Dem Dàkóráá C Pst write.Perf

Assuming that the adverb in the example (34b) is a topic position, [Spec, TopP], the ungrammaticality of the examples (35e) and (35f) suggests that relative clauses lack a TopP projection. In fact, no topicalization is allowed in Dàgáárè relative clauses.

Now, notice that the subject in the relative clause must precede the conplementizer. We assume, adopting Rizzi (1997), that the left periphery of the CP domain is decomposed into layers of functional categories: TopicP (TopP), ForceP (ForceP), FocusP (FP), and FinitenessP (FinP). ${ }^{14}$ The natural conclusion then will be that the Fin head has an EPP feature just like T, and requires the subject - the closest element - to move to its specifier (see Hiraiwa, 2005 and Chomsky, 2000, 2004). In fact, such a subject movement over C is well attested in some other Gur languages (Hiraiwa, 2005, 2008).

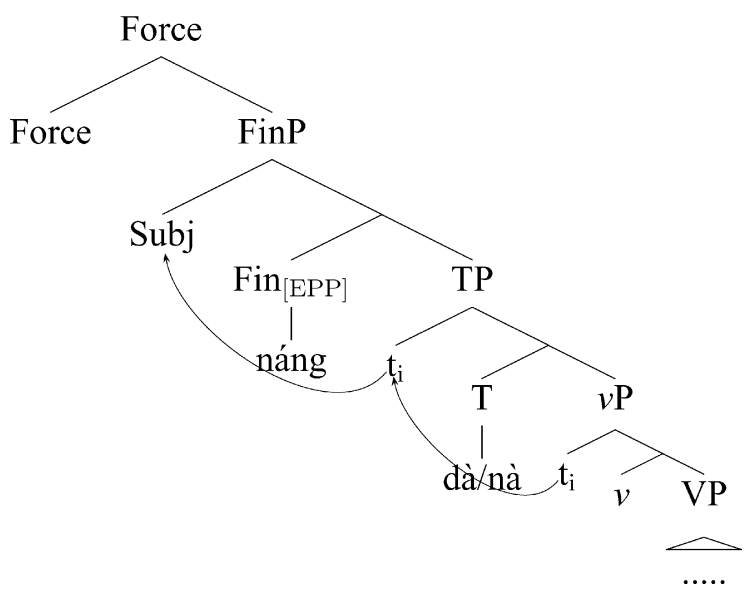

\subsection{Interim summary}

To summarize, Dàgáárè relativization involves a left-moved head noun and the complementizer (Fin) náng. The subject obligatorily moves to [Spec, FinP]. The relativized head noun optionally takes a definite determiner and a

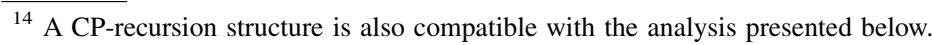


demonstrative for definite relative clauses. The particle náng is best understood as a complementizer given the cooccurrence and word order evidence. In contrast, the placements of the demonstrative ná show that it is not a complementizer. Rather it is a constituent of the relativized noun phrase.

(37) a. The relativized head always appears at the left edge of the clause.

b. The demonstrative ná is not a constituent of the relative clause (i.e. it is not a complementizer, either).

c. The complementizer náng is located structurally higher than other preverbal TAMP particles.

d. Movement is involved.

Having established the internal structure of the relative clauses in Dàgáárè, in the next section, we will show evidence that the relativized head nouns are still located internally to the relative clauses.

\section{Left-headed but internally-headed relative clauses}

Given the fact that Dàgáárè is an SVO language, it is indeed expected that its relativized head noun appears at the left periphery, not at the right periphery, according to Emmon Bach's correlation between word order and Whmovement (see Bach, 1971; see also Bresnan, 1970). As we have shown in the first half of this article, Dàgáárè does not allow what is clearly considered to be in-situ HIRCs. Namely, the relativized head noun cannot remain in-situ. Rather, the relativized head noun is always placed at the left edge of the clause, just as in English. This is apparently in accordance with Peter Cole's generalization that HIRCs are limited to SOV languages (see Cole, 1987). However, Hiraiwa (2005) argues that such a word order generalization does not hold cross-linguistically and shows that there are Gur languages that have SVO word order but still allow in-situ HIRCs perfectly, as first noticed by Tellier (1989). The important question, then, concerns the precise structure of the relative clause in Dàgáárè-where does the fronted relativized head noun reside, and is it external or internal to the relative clause? If evidence suggests that it is internal despite its appearance, Dàgáárè provides a significant example of another new type of HIRC: left-headed HIRCs. As we have seen, however, mere word order does not tell us whether the left-peripheral head is internal or not. $^{15}$

Basilico (1996) notes the existence of HIRCs in Diegueño and Mojave with its relativized head displaced but yet clause-internally. As we have seen in Section 1, movement of the head noun in front of the subject is optional and he argues that it targets the TP-adjoined position. In this section, we argue that Dàgáárè relative clauses are indeed internally-headed and hence instantiate ex-situ HIRCs. However, Dàgáárè crucially differs from those languages in that the landing site of the internal head noun is the CP-edge and the movement is always obligatory.

(38) a. The head noun in Dàgáárè is obligatorily moved.

b. The landing site is the edge of $\mathrm{CP}-[$ Spec, ForceP].

These are in fact naturally expected given that Dàgáárè is a Wh-movement language and there is cross-linguistic parallelism between $W h$-questions and relativization. Recall also that Dàgáárè does not have scrambling.

The proposed structure is shown in (39) (successive-cyclic movement is not indicated for simplicity). In other words, the left-moved head noun is located at the edge of $\mathrm{CP}$, but crucially not outside of the relative clause.

\footnotetext{
${ }^{15}$ Dàgáárè relative clauses do show reconstruction effects. In the example (i), the subject pronoun of the embedded clause must be disjoint with the R-expression within the relativized head noun. Thus, the Condition C violation shows that raising is involved in relativization in Dàgáárè. However, it still does not tell us whether the final structure of relative clauses is internally-headed or externally-headed (Recall Section 1).

(i) ̀̀ nyé lá à Dàkóráá fótó ná $\grave{o}_{* i / j}$ náng péntì.

$1 \mathrm{Sg}$ see.Perf F D Dàkóráá photo Dem $3 \mathrm{Sg} \mathrm{C}$ paint.Perf

'I saw Dàkóráá's picture that he painted.'

As a side note, a reflexive binding via reconstruction does not work in Dàgáárè for some reason that we do not understand.

(ii) *ǹ nyé lá à ò mèngé fòtò Dàkóráá náng péntì.

$1 \mathrm{Sg}$ see.Perf F D 3Sg self photo Dàkórá C paint.Perf

'I saw the picture of himself that Dàkóráá painted.'
} 
Translating a CP-recursion structure into Rizzi's articulated CP clausal structure, the head noun undergoes an $\overline{\mathrm{A}}$-movement to a higher $\mathrm{CP}$ layer [Spec, ForceP]. Recall that the complementizer náng has an EPP feature and hence the closest DP - the subject - moves to [Spec, FinP]. Because the determiner à lacks an EPP feature in Dàgáárè (see Section 2), the relativized head noun does not move to [Spec, DP], remaining internally to the relative clause. ${ }^{16}$

\section{Left-headed HIRC}

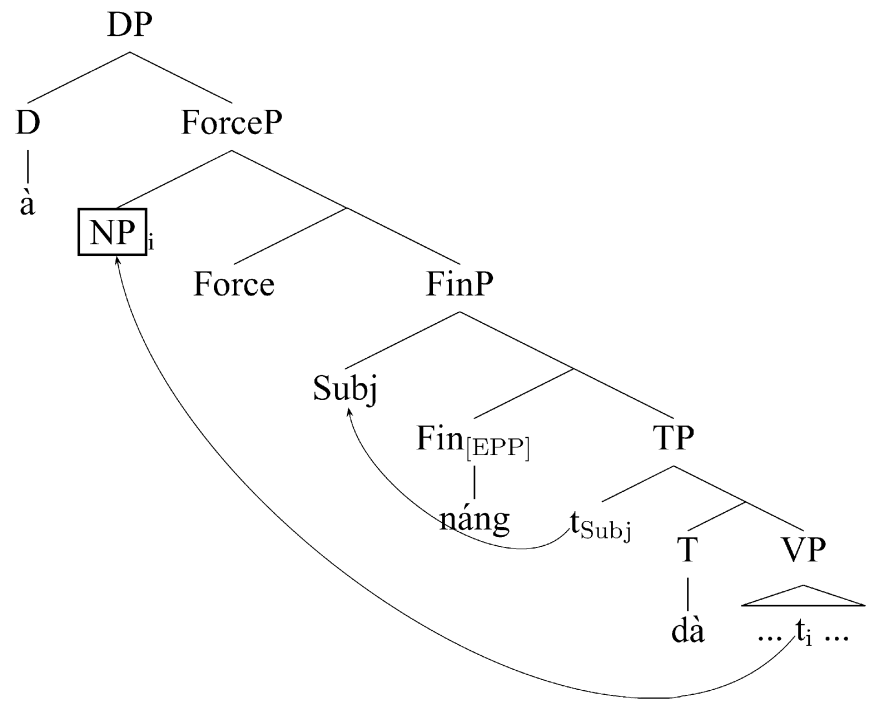

Dàgáárè strikingly differs from some other Gur languages (such as Bùlì; see Hiraiwa, 2005, 2008) in that an in-situ HIRC is impossible. Furthermore, unlike Diegueño and Mojave, whose head-raising is simply an option, the movement of the head noun is obligatory. If correct, then the existence of Dàgáàrè-type left-headed HIRCs is of considerable typological significance. The existence of left-headed HIRCs, if established, also has far-reaching consequences for the cross-linguistic typology of HIRCs. First, this type of ex-situ HIRCs has not been observed in the literature. Second, most importantly, it suggests a totally new picture of the typology of HIRCs (cf. Gorbet, 1977; Cole, 1987; Culy, 1990) and a careful re-examination of the relative clauses that have been simply assumed to be HERCs. Furthermore, it provides another piece of evidence against Cole's Generalization (Cole, 1987) that HIRCs are restricted to languages with null pronouns and SOV word order; Dàgáárè neither allows null pronouns nor shows SOV word order.

In the reminder of this article, we demonstrate that Dàgáárè relativization is an instance of left-headed HIRCs, based on two empirical arguments - coordinated PP relativization and coordinated possessor relativization. The evidence is based on syntactic constituency, which is one of the most solid tests for syntactic structures in transformational syntactic theory. The conclusion is further supported by the ungrammaticality of extraposition of relative clauses and the Indefiniteness Restriction.

\subsection{PP relativization and pied-piping}

Dàgáárè has a number of postpositions. For example, the postposition póó 'in’ takes a noun phrase as its complement.

(40) Dàkóráá gâng lá [PP à lóórè póó].

Dàkóráá lie.Perf $\mathrm{F} \quad \mathrm{D}$ car in

'Dàkóráá slept in the car.'

\footnotetext{
${ }^{16}$ See Rizzi (1997) for evidence that a relativized head noun in Italian is located in [Spec, ForceP], higher than a position for Wh-phrases. The fact that $W h$-phrases and focused elements are obligatorily marked with the focus marker lá in Dàgáàrè shows that they are considered to be in [Spec, FocP], in contrast with relativized head nouns, which never take such a marker.
} 
In Dàgáárè, there are two ways to relativize the complement of $\mathrm{P}$ : either a $\mathrm{P}$ is stranded with a resumptive pronoun of the relativized head noun as in the example (41a) or it is pied-piped with the relativized head to the initial position as in the example (41b). In the former case, the resumptive pronoun is obligatory. ${ }^{17}$

\section{Relativization and pied-piping of $\mathrm{P}$}

a. ǹ dá lá à [ForceP lóórè nă [Dàkóráá náng gâng ò póó]].

$1 \mathrm{Sg}$ buy.Perf F D car Dem Dàkóráá $\mathrm{C} \quad$ lie.Perf $3 \mathrm{Sg}$ in

'I bought the car in which Dàkóráá slept.'

b. ǹ dá lá à [ForceP lóśrè nǎ póó [Dàkóráá náng gâng]].

$1 \mathrm{Sg}$ buy.Perf F D car Dem in Dàkóráá $\mathrm{C}$ lie.Perf

'I bought the car in which Dàkóráá slept.'

That both relative clauses in (41) allow the same interpretaion in which the relativized head is lóbè alone is supported by the fact that they can be an answer to a Wh-question (42).

lóó-bóò lá ká fó dà?

car-which F C 2Sg buy.Perf

'Which car did you buy?'

If the relative clause is internally-headed and left-headed, the structure should be as follows.

\section{Left-headed HIRC}

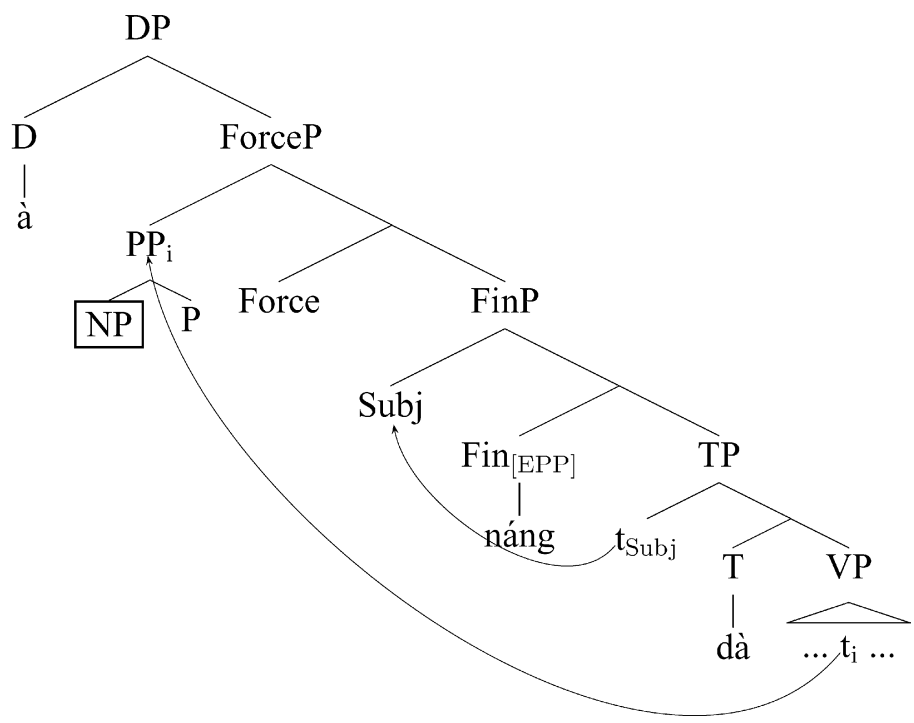

The pied-piping facts alone, however, do not provide us with decisive evidence for left-headed HIRCs. In fact, they could also be accounted for if the relative clauses in Dàgáárè were externally-headed (whether (1a) or (3)). Under such an analysis, one might say that the PP (the postposition and the resumptive pronoun) is actually moved to [Spec, ForceP] and the relativized head noun is base-generated in a position external to ForceP (it is base-generated externally in traditional analyses or is raised in Bhatt's (2002) analysis). This hypothetical derivation is illustrated in the structure (44).

\footnotetext{
${ }^{17}$ There is a semantic effect of pied-piping. The relative clause without pied-piping only has an interpretation in which what was bought was 'the car'. On the other hand, when pied-piping takes place, the relative clause becomes ambiguous: what was bought was 'the car' or 'the inside of the car' (possibly, the interior of the car alone). Sometimes, the latter interpretation is more readily available, but in principle, (41b) allows the same interpretation as (41a). We ignore the latter interpretation in this article, because it is irrelevant to our main focus.
} 
(44) Externally-headed structure

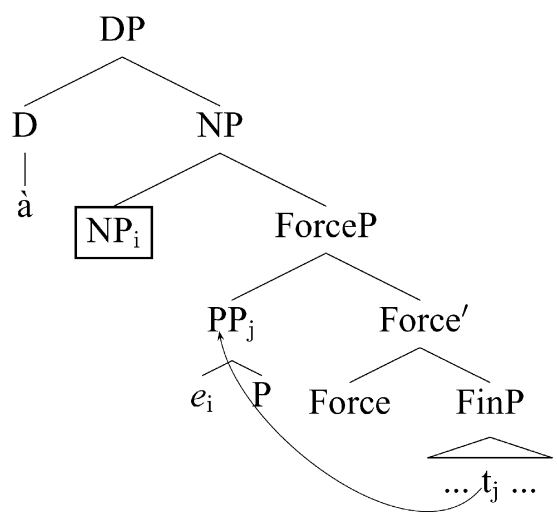

Of course, this analysis poses a conceptual question: why is the PP moved to [Spec, ForceP]? Furthermore, even if one could somehow motivate this movement, it would be necessary to restrict such a movement only in cases where the complement of $\mathrm{P}$ is an empty category.

However, this analysis makes a wrong prediction. The derivation (44) should expect that the coordination of PP relative clauses would be grammatical, with the PPs fronted to [Spec, ForceP] in each conjuncts. This is in fact grammatical in English, whose relative clauses are allegedly externally-headed (see Bhatt, 2002 for extensive evidence).

(45) This is the car [ForceP in which John slept] and [ForceP on which Mary slept].

(46) HERC and coordination of PP relative clauses

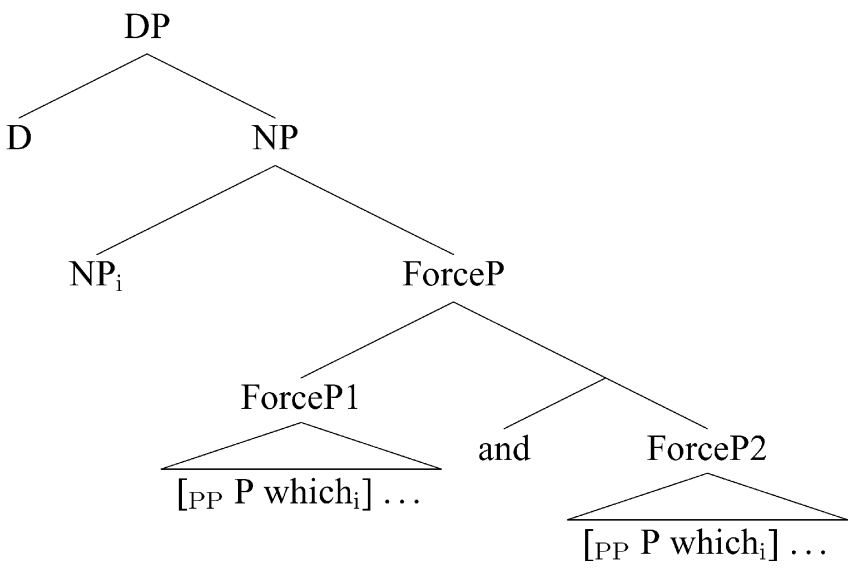

However, such examples are ungrammatical in Dàgáárè, contrary to the prediction. As shown in (47b), when the $\mathrm{P}$ is pied-piped, the sentences result in ungrammaticality. Instead, the PPs must be left in-situ with resumptive pronoun as in (47a).

(47) Pied-piping and coordination

a. à [lóórè ná [Dàkóráá náng gâng ò póó] kà [Déré gâng ò zû] D car Dem Dàkóráá C lie.Perf 3Sg in Conj. Déré lie.Perf 3Sg on lá nyé].

Cop this

'The car in which Dàkóráá slept and on which Déré slept is this.' 
b. *à [lóórè ná [(ò) póó Dàkóráá náng gâng] kà [(ò) zû Déré gâng]

$\mathrm{D}$ car Dem 3Sg in Dàkóráá C lie.Perf Conj. 3Sg on Déré lie.Perf

lá nyéc].

Cop this

'The car in which Dàkóráá slept and on which Déré slept is this.'

One might wonder if the sentence (47b) is ungrammatical, because the movement of PP in the second is not licensed for some reason. However, the sentence is still ungrammatical even if the PP is left in-situ with the resumptive pronoun.

(48) ?*à lóórè ná [(ò) póó Dàkóráá náng gâng] kà [Déré gâng ò zû] lá

$\mathrm{D}$ car Dem 3Sg in Dàkórá C lie.Perf Conj. Déré lie.Perf 3Sg on Cop

nyé.

this

'The car in which Dàkóráá slept and on which Déré slept is this.'

All of these facts are mysterious if the relative clause in Dàgáárè permits an externally-headed structure at all.

The ungrammaticality of (47b) is explained if the relative clause in question has the head-internal structure as illustrated in (49). This is because the PP and the head noun must form a constituent and hence there is no way to coordinate CPs excluding the relativized head noun and to produce the surface form (47b).

(49)

Left-headed HIRC and coordination of PP relative clauses

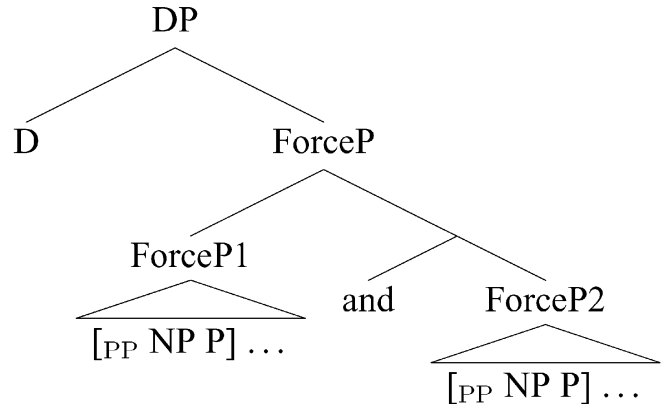

On the other hand, the example without pied-piping (47a) is naturally explained as a result of Across-the-Board extraction of the possessor relativized noun phrase as depicted in (50).

(50) Left-headed HIRC and coordination of in-situ PP relative clauses

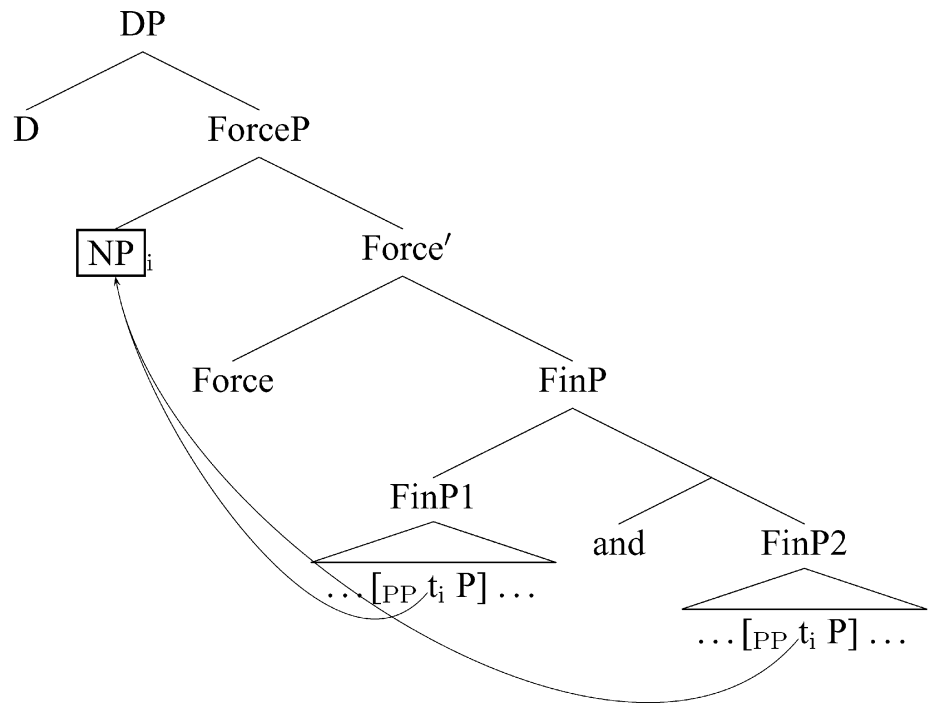




\subsection{Possessor relativization and pied-piping}

The second evidence comes from possessor relativization. Recall that Dàgáárè allows possessor relativization (51a). Of great importance for our discussion is the fact that the sentence (51b) is also grammatical, where the whole possessor-possessee complex has been moved to the left (the resumptive pronoun is required in (51a) and slightly preferred in (51b).

(51) Possessor relativization without pied-piping
a. ̀̀ dà nyé lá à [pógó ná [ǹ náng sóré *(ò) gánè dèyâng]]. 1Sg Pst see.Perf F D woman Dem 1Sg C read.Perf 3Sg book last.year
'I saw the woman whose book I read last year.'
b. ̀̀ dà nyé lá à [pógó ná ?(ò) gánè [ǹ náng sóré dèyâng]]. $1 \mathrm{Sg}$ Pst see.Perf F D woman Dem 3Sg book 1Sg C read.Perf last.year
'I saw the woman whose book I read last year.'

The syntactic derivation of possessor relativization with pied-piping is represented below where $\mathrm{NP}_{1}$ is gánè and $\mathrm{NP}_{2}$ is the possessor pógó ná.

\section{Left-headed HIRC (pied-piping of the possessed NP)}

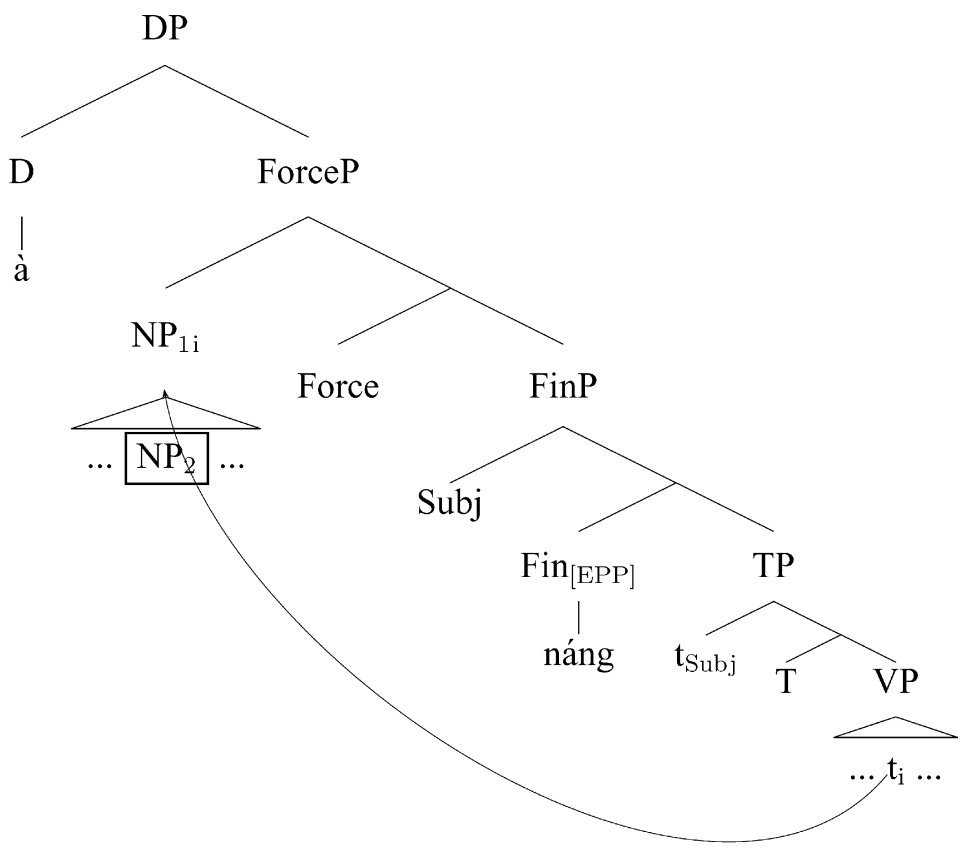

Again, an interaction of coordination and pied-piping demonstrates that the relativized head is still internal to the relative clause. Compare the English examples with the Dàgáárè counterparts. While English relative clauses are externally-headed and hence allow coordination of relative clauses with fronted possessed NPs (with the relative pronouns), Dàgáárè disallows such coordination. 
(54) HERC and coordination of possessor relative clauses

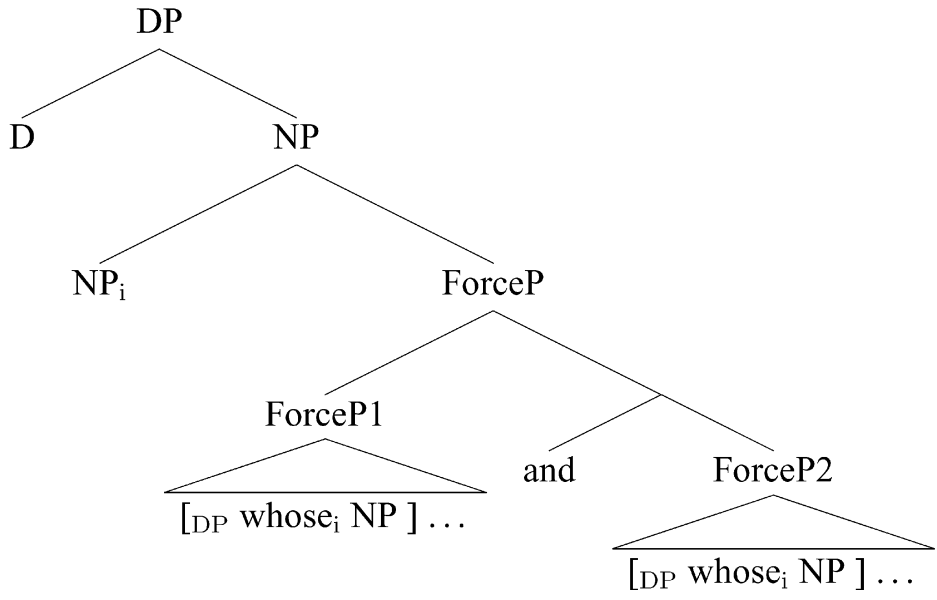

This is expected given that the relative clauses in English are externally-headed and the relativized head noun and the relative pronoun (plus the possessed NP) do not form a syntactic constituent. In contrast, in left-headed HIRCs, the relativized possessor NP and the pied-piped possessed NP form a syntactic constituent and are located in [Spec, ForceP] (see (52)). Hence the coordination fails with pied-piping because the form is never derivable under the leftheaded HIRC structure, as shown in the examples (55) and (56).

Possessor relativization and pied-piping

a. ̀̀ pùorí lá à [pógò ná [ǹ náng sóré ò gánè] kà [Déré 1Sg greet.Perf F D woman Den 1Sg C read.Perf 3Sg book Conj. Déré bòngè ò séré]].

know $3 \mathrm{Sg}$ husband

'I greeted the woman whose book I read and whose husband Déré knows.'

b. *ǹ pùòí lá à [pógò ná [(ò) gánè ǹ náng sóré] kà [(ò)

1Sg greet.Perf F D woman Den 3Sg book 1Sg C read.Perf Conj. 3Sg

séré Déré bòngè]] .

husband Déré know

'I greeted the woman whose book I read and whose husband Déré knows.'

c?*ǹ pùòí lá à [pógò ná [(ò) gánè ̀̀ náng sóré] kà [Déré

1Sg greet.Perf F D woman Den 3Sg book $1 \mathrm{Sg} \mathrm{C}$ read.Perf Conj. Déré

bòngè ò séré]].

know $3 \mathrm{Sg}$ husband

'I greeted the woman whose book I read and whose husband Déré knows.'

(56) Lett-headed HIRC and coordination of pied-piped possessor relative clauses

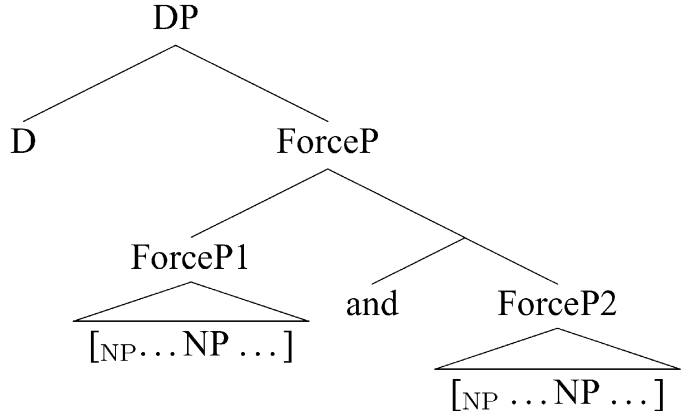


The coordination is licit as long as the possessed NPs are left in-situ, as we have also seen in PP relativization. ${ }^{18}$ (57)

Left-headed HIRC and coordination of possessor relative clauses

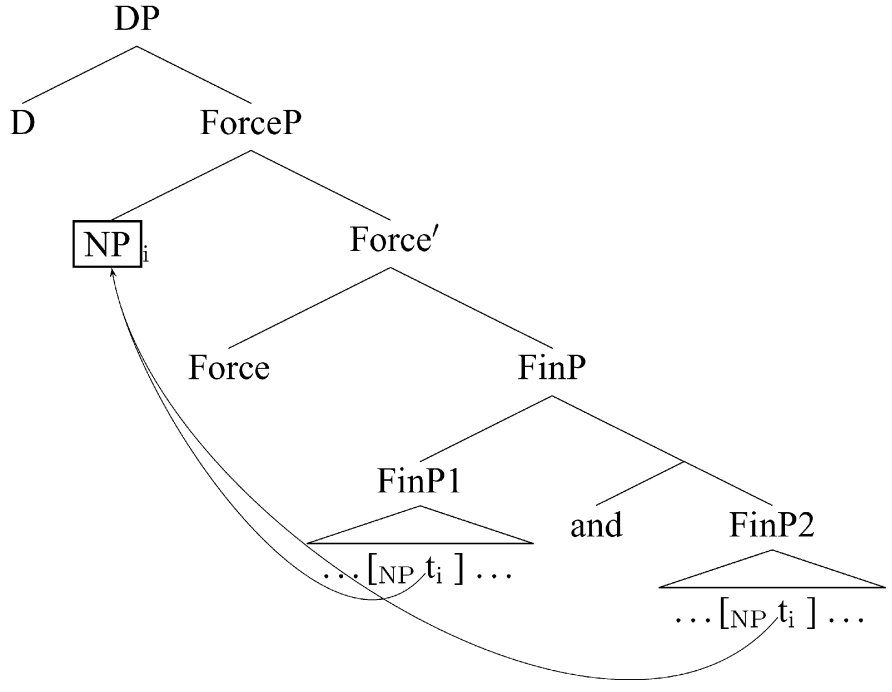

\subsection{Extraposition}

The conclusion that relative clauses in Dàgáárè are not externally-headed is confirmed by the fact that extraposition of relative clauses are strictly ungrammatical in Dàgáárè, unlike in English, whose relative clauses are arguably externallyheaded.

(58) a. I read the book [ForceP which John wrote last year] yesterday.

b. I read the book yesterday [ForceP which John wrote last year].

Note that in left-headed HIRCs, the ForceP contains the relativized head NP and hence the former cannot be extraposed in such a way that excludes the latter. In externally-headed relative clauses like those in English, the ForceP is either adjoined to an NP or is the complement of an N. Thus a relative clause can be extraposed independently of the relativized head NP.

*Extraposition of relative clauses

a. ̀̀ dà sóré $e_{i}$ lá à [ForceP gánè ná [Dàkóráá náng ngmàà $e_{\mathrm{i}} / * \grave{o}_{\mathrm{i}}$ 1Sg Pst read.Perf F D book Dem Dàkóráá $\mathrm{C} \quad$ write.Perf $\phi / 3 \mathrm{Sg}$ dèyâng]] zààméng. last.year yesterday 'I read the book that Dàkóráá wrote last year yesterday.'

b. *ǹ dà sóré ${ }_{i}$ lá à gánè ná zààméng [Dàkóráá náng ngmàà 1 Sg Pst read.Perf F D book Dem yesterday Dàkóráá C $e_{\mathrm{i}} / *^{*} \grave{o}_{\mathrm{i}} \quad$ dèyâng]. write.Perf $\phi / 3 \mathrm{Sg}$ last.year

'I read the book that Dàkóráá wrote last year yesterday.'

\footnotetext{
${ }^{18}$ To complete our arguments, we should note that coordinated PP relativization and coordinated possessor relativization behave exactly in the same way as normal relative clauses in terms of island effects. Thanks to an anonymous reviewer for pointing this out.

(i) *à lóbrè ná [ǹ nyé lá à [pógò ná náng gâng ò póó]] kà [ǹ nyé lá à [dóo

D car Dem 1Sg see.Perf F D woman Dem C lie.Perf 3Sg in Conj. 1Sg see.Perf F D man

ná gâng ò zû]] lá nyé.

Dem lie.Perf $3 \mathrm{Sg}$ on Cop this

'The car in which $\mathrm{I}_{\mathrm{i}}$ saw the woman who slept $e_{\mathrm{i}}$ and on which $\mathrm{I}_{\mathrm{j}}$ saw the man who slept $e_{\mathrm{j}}$ is this.'
} 
We should mention that this point can also be illustrated with coordinated relative clauses.
a. ̀̀ pùòí
lá à [pógó
ná [ǹ năng sóré
ò gánè] kà [Déré

$1 \mathrm{Sg}$ greet.Perf F D woman Den $1 \mathrm{Sg} \mathrm{C}$ read.Perf $3 \mathrm{Sg}$ book Conj. Déré

bóngé ò séré]] zààméng.

know 3Sg husband yesterday

'I greeted the woman whose book I read and whose husband Déré knew yesterday.'

b. *’̀̀ pùòí lá à pógó ná zààméng [ǹ năng sóré ò gánè]

$1 \mathrm{Sg}$ greet.Perf F D woman Den yesterday $1 \mathrm{Sg} \mathrm{C}$ read.Perf 3Sg book

kà [Déré bóngé ò séré].

Conj. Déré know 3Sg husband

'I greeted the woman yesterday whose book I read and whose husband Déré knew.'

This eliminates the possibility that coordinated possessor relative clauses have a totally different structure.

Hulsey and Sauerland (2006) show that extraposition is ungrammatical even in English, when a raising derivation - a head-internal structure in their terms - is forced. They argue that English relative clauses are structurally ambiguous between head-external and head-internal structures. Thus, when an idiom chunk or reconstruction is involved as in (61) and (62), extraposing the relative clause is prohibited, just as we have seen in Dàgáárè (the examples are cited from Hulsey and Sauerland, 2006).

(61) a. Mary praised the headway that John made.

b. *Mary praised the headway last year that John made.

(62) a. I saw the picture of himself $f_{\mathrm{i}}$ that $\mathrm{John}_{\mathrm{i}}$ liked.

b. $\quad$ *I saw the picture of himself $f_{i}$ yesterday that $J o h n_{i}$ liked.

Thus the ungrammaticality of extraposition in Dàgáárè and a certain type of relative clauses in English are expected given the structure (39).

\subsection{Non-restrictives and the indefiniteness restriction}

Another piece of corroborating evidence is the lack of appositive relative clauses in Dàgáárè. Dàgáárè lacks non-restrictive relative clauses with a proper noun as a head noun, as indicated by the ill-formed example (63).

\section{(63) Non-restrictive relative clause}

?*ǹ dà nyé lá Dàkóráá náng ngmàà à gánè dèyâng.

1Sg Pst see.Perf F Dàkóráá C wrote D book last.year

'I saw Dàkóráá, who wrote the book last year.'

If the proper noun Dàkóráá is accompanied by the definite determiner and the demonstrative, the relative clause obligatorily becomes restrictive, which restricts a set of people whose name is Dàkóráá.

(64) Restrictive relative clause

ǹ dà nyé lá à Dàkóráá ná náng ngmàà à gánè dèyâng.

1Sg Pst see.Perf F D Dàkóráá Dem C wrote D book last.year

'I saw the Dàkóráá who wrote the book last year.'

The absence of non-restrictive relative clauses in Dàgáárè would be puzzling given that no other principles prevented the language from allowing non-restrictives. 
However, it straightforwardly follows if the structure of the relative clauses in Dàgáárè is always internally-headed. It has been well known in the literature that HIRCs are cross-linguistically subject to what Williamson (1987) calls The Indefiniteness Restriction. Thus, relativized head nouns of HIRCs must always be indefinite. A famous example in Lakhota is cited below. Note that the relativized head noun can take the indefinite determiner, but not the definite determiner.

\section{Lakhota (Williamson 1987: 171)}

a. [[[Mary owįža wą kağe] ki] he] ophewathụ. Mary quilt Id make D Dem $1 \mathrm{Sg}$-buy

'I bought the quilt that Mary made.'

b. *[[[Mary owiža ki kağe] ki] he] ophewathų.

Mary quilt D make D Dem 1Sg-buy

'I bought the quilt that Mary made.'

Not surprisingly, an in-situ HIRC in Lakhota disallows a non-restrictive relative clause. Thus, the following sentence, with the first person pronoun as an internal head, is ungrammatical.

Lakhota (Williamson 1987: 175)

*[[(Miye) makuže $] \mathrm{ki} / \mathrm{cha}]$ wichawota ki ekta mnj kte. 1Sg.Emph 1Sg.sick D/D feat D to 1Sg.go Fut

'I, who am sick, will go to the feat.'

Now, we correctly expect that a proper noun, which is clearly a definite noun phrase, cannot appear as a relativized head in Dàgáárè despite the fact that it appears at the left periphery as in English. This is so, precisely because the relative clause is internally-headed and hence must conform to the Indefiniteness Restriction. And to the best of our knowledge, there is no language attested at this point in which non-restrictives are formed using HIRCs.

Finally, it should be emphasized that the coordination facts, the impossibility of extraposition, as well as the Indefiniteness Restriction all demonstrate that relative clauses in Dàgáárè are unambiguously internally-headed. If Dàgáárè allowed externally-headed relative clauses in addition to internally-headed relative clauses, the coordinated PP/possessor relativization, extraposition, and a non-restrictive relative clause should all be grammatical. ${ }^{19}$

\subsection{Alternatives}

The editors for Lingua pointed out a possibility that the coordinated relative clauses in English and Dàgááre actually involve a deletion of an identical relativized noun phrase. The schematic structure would then be something like below.

a. I greeted [the woman] [whose book I read yesterday] and [the woman] [whose husband John knows well].

b.

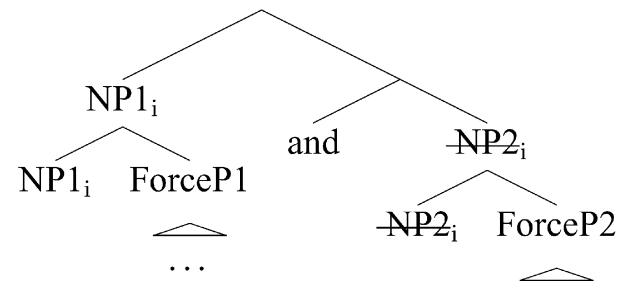

\footnotetext{
${ }^{19}$ Recall that relativized head nouns in Dàgáarè are marked with the demonstrative ná. This raises a question about the Indefiniteness Restriction. We assume, however, that the demonstrative in this environment is grammaticalized and has lost definiteness and suggest that it may function as a specific indefinite determiner. Some Gur languages use a dedicated specific indefinite determiner to mark a relativized head. See Hiraiwa (2008, in preparation) for a comparative study of relative clauses in Gur languages and the role of specific indefinite determiners. See Greenberg (1978) for grammaticalization of demonstratives.
} 
Under this analysis, what are syntactically coordinated are two identical noun phrases - external relativized head nouns - , rather than relative clauses. But phonological deletion of the second identical NP gives rises to the appearance that two relative clauses (ForcePs) are are coordinated. If this is a possible analysis, the apparent coordination facts lose their force. For example, one could argue that the grammaticality of the coordination in English is due to the deletion rule, while its ungrammaticality in Dàgáárè is due to an absence of such a rule (whatever an explanation for this asymmetry may be). If so, the (un)grammaticality in English and Dàgáárè would not tell us anything about the syntactic structures of their relative clauses.

Of course, such an analysis requires a principle of deletion that does not overgenerate unwanted sentences and such a rule must also be general enough. We do not think of any such principle, but let us simply suppose that such a deletion existed. However, this alternative can be explicitly excluded for Dàgáárè because the language uses different coordination markers for nominal and clausal coordinations. While the clausal coordinator is $k a$ as we have seen above, the nominal coordinator is $n e$.
Dàkóráá nê/*kà
Ayúó
Dàkóráá and $\mathrm{nominal}_{\text {/and }}$ clausal Ayúó
'Dàkóráá and Ayúó'

The use of $k a$ in the sentences (47a) and (55a) clearly demonstrates that the coordinated relative clauses in question are an instance of clausal coordination. If it were a nominal coordination with the second identical noun elided as in the structure (67b), the coordinator should have been $n e$. Thus the alternative analysis $(67 \mathrm{~b})$ is excluded for Dàgáárè, which supports our conclusion that Dàgáárè relative clauses are internally-headed.

In the case of English, the situation is a little more complicated because the coordinator and is used both for nouns and clauses. However, the same point can be made by using the coordinator but. It can conjoin clauses but not noun phrases.
a. I ate a banana and/*but a mango.
b. I ate a banana and/but she ate a mango.

Now if the sentences (45) and (53) were a coordination of noun phrases as represented in the structure (67b), we would expect that a use of but would lead to ungrammaticality. This prediction is not borne out, however.

I met the woman [whose son I teach] but [whose daughter I don't know well].

Thus, it is legitimate to think that the coordinated relative clauses in question do not involve an elided head noun in either language. Therefore, the asymmetry in the coordination of relative clauses between English and Dàgáárè shows the asymmetry in the structure: the externally-headed structure for English and the internally-headed structure for Dàgáárè.

Let us further consider another alternative analysis that an anonymous reviewer pointed out, in which the entire PP or the entire possessor-possessee NP is an external head in the traditional adjunction analysis or in Bhatt's (2002) raising and reprojection analysis.

a.

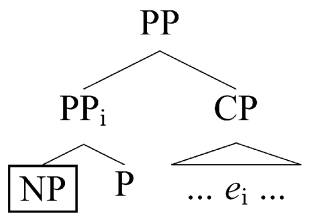

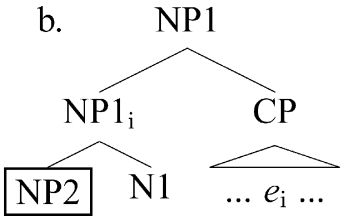

The obvious difficulty is to characterize the proper relation between a higher verb and these complex noun phrases. The analysis of PP relativization (71a) means that the entire category is a PP, which cannot function as an argument in a higher clause. Indeed, such a PP cannot combine with the verb 'to buy' without a relative clause to mean 'I bought the car', whereas the PP relativization with pied-piping has exactly that interpretation. 
a. *ǹ dà dá lá [PP à lóórè nă póó].

1Sg Pst buy.Perf F D car Dem in

'I bought the car.'

b. $(=(41 b))$

ǹ dá lá à lóśrè nă póó Dàkóráá náng gâng.

1Sg buy.Perf F D car Dem in Dàkóráá C lie.Perf

'I bought the car in which Dàkóráá slept.'

The same difficulty arises for the possessor relativization (71b). Again, the noun phrase without a relative clause in the example (73a) only allows the interpretation in which the entire noun phrase is a thematic object of the verb ('I saw the woman's book'). In contrast, the one with a relative clause in the example (73b) allows the interpretation in which only the possessor NP1 is a thematic object of the verb. This is unexpected under the head-external analysis as shown in the derivations (74), because in either example, the same noun phrase à pógó ná is in the same position - the direct sister position of the verb,
a. ̀̀ záà
dà nyé
lá à pógó ná gánè.

$1 \mathrm{Sg}$ yesterday Pst see.Perf F D woman Dem book

'I saw the woman's book yesterday.' '*I saw the woman with a book.'

b. $(=(51 b))$

ǹ dà nyé lá à pógó ná ?(ò) gánè ǹ náng sóré dèyâng.

1Sg Pst see.Perf F D woman Dem 3Sg book 1Sg C read.Perf last.year

'I saw the woman whose book I read last year.'

a.

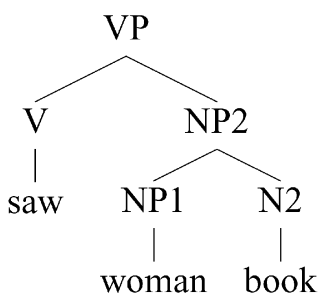

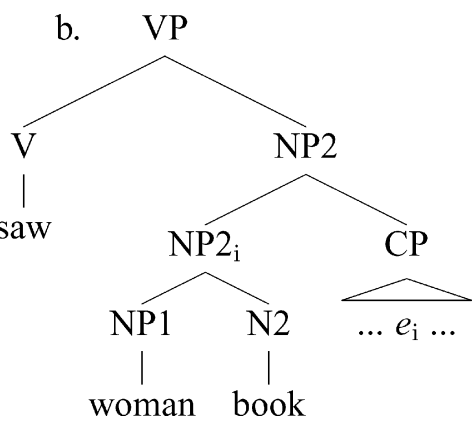

No such problem arises if the relative clauses are internally-headed even though left-headed in Dàgáàrè on the surface. In fact, this kind of phenomena are also observed in other Gur languages that allow in-situ HIRCs. In what appear to be clearly in-situ HIRCs (as well as ex-situ HIRCs), possessor relativization and PP relativization are semantically felicitous, as illustrated in the examples (75) and (76) from Bùlì (see Hiraiwa, 2005 for extensive discussions about Bùli). ${ }^{20}$

Bùlì: Relativization and pied-piping of $P$
a. ̀̀ dá [Àtìm àlī gwà ló:-dī:y pó lá].
1Sg buy.Perf Atim C lie.Perf car-Rel in Dem
'I bought the car in which Atim slept.'
(In-situ)
b. ǹ dá [ló:-dī:y àtì Àtìm gwà dì pó lá].
1Sg buy.Perf car-Rel C Atim lie.Perf 3Sg in Dem
'I bought the car in which Atim slept.'
(Ex-situ)

\footnotetext{
${ }^{20}$ See Hiraiwa (2008) for parametric differences between Dàgáárè-type languages and Bùlì-type languages among Gur languages, and for a theoretical proposal. 
c. ̀̀ dá [ló:-dī:y pó àtì Àtìm gwà lá].

1Sg buy.Perf car-Rel in C Atim lie.Perf Dem

'I bought the car in which Atim slept.'

(Ex-situ)

(76) Bùlì: Possessor Relativization

a. Àtìm dà [Àmòak àlī ymì̀ìì gbán-kā:y nà:y-ká lá].

Àtìm bought Àmòak C designed book-Rel cover-D Dem

'Àtìm bought the book whose cover Àmòak designed.'

(In-situ)

b. Àtìm dà [gbán-kā:y àtì Àmòak ymìrìì *(kà) nà:y-ká lá].

Àtìm bought book-Rel C Àmòak designed 3Sg cover-D Dem

'Àtìm bought the book whose cover Àmòak designed.'

(Ex-situ)

c. Àtìm dà [gbán-kā:y nà:y-kă àtì Àmòak jmìrìì lă].

Àtìm bought book-Rel cover-D C Àmòak designed. Dem

'Àtìm bought the book whose cover Àmòak designed.'

(Ex-situ)

\section{Typological implications}

Having established that relative clauses in Dàgáárè are left-headed HIRCs, we would like to consider some typological implications (see Hiraiwa, in preparation for extensive discussions on cross-linguistic typology of HIRCs).

In the typology of Wh-questions, three types of language have been attested: Wh-in-situ languages, optional Whmovement languages, and $W h$-movement languages.
a. Wh-in-situ, $* W h$-movement: Chinese, etc.
b. Wh-in-situ, Wh-movement: French, Bùlì, etc.
c. *Wh-in-situ, Wh-movement: English, Bulgarian, Dàgáárè, etc.

Similarly, there are theoretically three possible types of HIRCs permitted by a parametric theory. There are languages that only allow in-situ HIRCs. There are also languages that allow both in-situ and ex-situ HIRCs. However, the third-type, a language that only allows ex-situ HIRCs (i.e. left-headed HIRCs), has been unattested in the previous literature. As we have shown, Dàgáárè bridges this missing gap in the typology of HIRCs.

(78) a. in-situ HIRCs, *ex-situ HIRCs: Navajo, etc.

b. in-situ HIRCs, ex-situ HIRCs: Diegueño, Bùlì, etc.

c. *in-situ HIRCs, ex-situ HIRCs: Dàgáárè

If we include HERCs, we obtain the following typology.

(79) Typology of relative clauses

\begin{tabular}{|c|c|c|c|}
\hline & Left-Headed & Internally-Headed & Right-Headed \\
\hline Head-External & English, French & (N/A) & Japanese, Chinese \\
\hline \multirow{2}{*}{ Head-Internal } & Dàgáárè , Diegueño & Lakhota, Diegueño & $? ? ?$ \\
\cline { 2 - 4 } & &
\end{tabular}


Let us touch on the two gaps in the chart (79). First, right-headed HIRCs should be in principle absent as long as specifiers are always located at the left-hand branch universally (Kayne, 1994; Chomsky, 1995). Thus the structure (80) is not possible under this assumption.

Right-headed HIRC

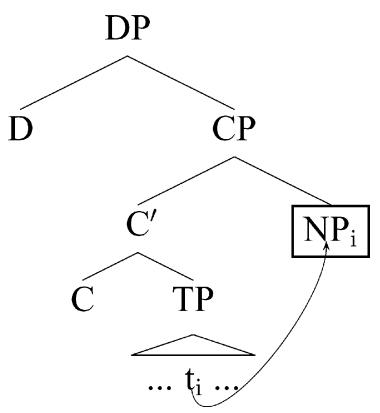

However, it is still technically possible to have right-headed HIRCs under this assumption. Suppose that the relativized head noun moves leftward to $[\mathrm{Spec}, \mathrm{CP}]$ as we have seen in Dàgáárè. Now suppose that the TP undergoes a remnant movement to a higher position. This derivation is illustrated below.

\section{Right-headed HIRC}

a.

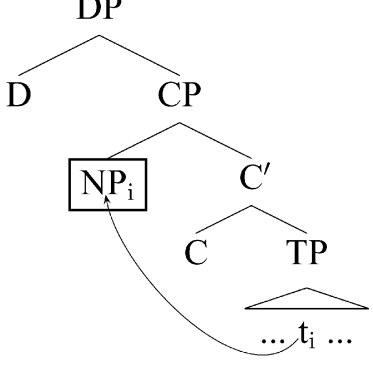

b.

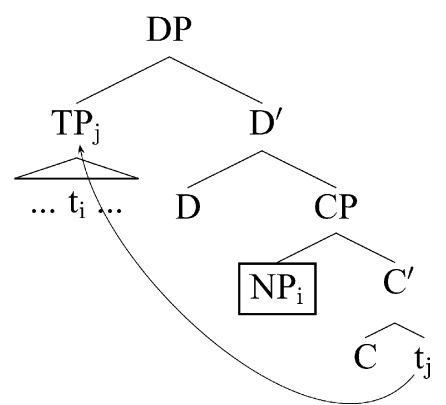

In fact, this is the way to derive right-headed relative clauses in Kayne's theory. As long as such TP movement is shown to be possible, we would expect right-headed HIRCs. The prediction is at least not borne out in Japanese. Japanese allows HIRCs as well as right-headed/prenominal relative clauses (Kuno, 1973; Kuroda, 1992). Now recall the Diegueño data in Section 1: Case-marking provides a direct clue about where a relativized head noun is located. Now in the HIRC example (82a), the relativized head noun ringo 'apple', being the subject in the relative clause, must take nominative Case-marking. In contrast, in the right-headed relative clause $(82 \mathrm{~b})$, the same relativized head must take accusative Case-marking, which comes from the higher verb tabe 'to eat'. This demonstrates that right-headed relative clauses in Japanese can never be internallyheaded.

\section{Japanese}

a. [teeburu-no ue-ni ringo-ga/*o oiteat-ta no]-o tabe-ta. table-Gen on-Loc apple-Nom/Acc put-Pst C-Acc eat-Pst 'I ate the apple that had been put on the table.'

(HIRC)

b. [t[eeburu-no ue-ni $t_{i}$ oiteat-ta] ringo $\left.\mathbf{o}_{\mathrm{i}}\right]-\mathbf{o} /{ }^{*}$ ga tabe-ta. table-Gen on-Loc put-Pst apple-Acc/Nom eat-Pst 'I ate the apple that had been put on the table.' (Right-headed HERC)

The other gap in the chart (79), internally-headed head-external relative clauses, is more straightforward. It is theoretically predicted to be impossible because a relative clause cannot be internally- and externally-headed at 
the same time, and indeed, to the best of our knowledge, no one has argued for this type of relative clause so far. $^{21}$

$$
\begin{aligned}
& \text { *Internally-headed HERC } \\
& {\left[\ldots \mathrm{H}_{\text {Case } \alpha} \ldots\right] \ldots \mathrm{V} / \mathrm{T}_{\text {Case } \alpha}}
\end{aligned}
$$

\section{Conclusions and further issues}

In conclusion, the availability of pied-piping in PP and possessor relativization shows that what looks like an externally-headed relative clause in Dàgáárè is indeed internally-headed, with the relativized head noun moved to the left edge but still remaining clause-internal. We have argued that the head obligatorily moves to [Spec, ForceP] just as a Wh-phrase does. Dàgáárè is different from the languages that Basilico (1996) discusses in that the movement is obligatory and not a scrambling. This is corroborated by the absence of scrambling in the language and by the fact that the language is an obligatory $W h$-fronting language as we have seen in Section $2 .^{22}$

Watanabe (2004) refutes the face-value correlation between HIRCs and Wh-in-situ (cf. Watanabe, 1991) based on Quechua and instead links the availability of HIRCs in Quechua to the availability of focus-in-situ. However, it is still not unreasonable to think that Wh-movement and the movement of the head noun of HIRCs utilize the same mechanism, as Watanabe $(2004,2006)$ argues. If so it is not surprising that the head noun in Dàgáárè always appears at the left periphery internal to $\mathrm{CP}$, although we have to leave open a fine-grained parametric theory of HIRCs.

We have demonstrated that Dàgáárè presents a new type of HIRC, called left-headed HIRC and this opens up a possible reconsideration of the facts of relative clauses in other languages in the light of this syntactic derivation. This is important in two respects. First, this type of ex-situ HIRCs has not been observed in the literature. Second, it suggests a totally new picture of the typology of HIRCs (cf. Gorbet, 1977; Cole, 1987; Culy, 1990) and a careful reexamination of the relative clauses that have been simply assumed to be HERCs. Furthermore, it provides another piece of evidence against Cole's Generalization (Cole, 1987) that HIRC is restricted to languages with null pronouns and SOV word order (see also Culy, 1990; Hiraiwa, 2008, in preparation); Dàgáárè neither allows null pronouns nor shows SOV word order. Needless to say, Cole's generalization was based on in-situ HIRCs, but a theory incorporating both in-situ and ex-situ HIRCs must be pursued in the future.

\footnotetext{
${ }^{21}$ Grosu and Landman (1998) and Grosu (2002) argue that HIRCs come in (at least) two types: the restrictive type and the maximalizing type. They argue that the latter excludes an existential reading and disallows stacking. Dàgáárè relative clauses do not stack. However, they do not exclude an existential interpretation.
}

(i) a. wìrrí áyì Dàkóráá náng dà dà vèc̀lé lá. horse.Pl two Dàkóráá $\mathrm{C}$ buy.Perf Pst be.good F

'Two horses that Dàkóráá bought were good.'

b. * d̀̀ dóré lá à gánè ná [Dàkóráá náng ngmàà dèyâng] [Áyúó náng dà

1Sg Pst read.Perf F D book Dem Dàkóráá C wrote last.year Áyúó C bought zààmêng].

yesterday

'I read the book that Dàkóráá wrote last year that Áyúó bought yesterday.'

We have to leave for future research a in-depth investigation of the semantics of HIRCs and its typology.

${ }^{22}$ Under this analysis, one might wonder if two instances of $\grave{a}$ might co-occur in a relative clause, one for the CP and the other for the internal head noun. The expectation fails, however.

(i) ̀̀ dà sóré ${ }_{i} \quad$ lá à (*à) gánè ná Dàkóráá náng ngmàà $e_{\mathrm{i}} /$ * $_{\mathrm{i}}$ dèyâng.

1 Sg Pst read.Perf F D D book Dem Dàkóráá C write.Perf $\phi / 3 \mathrm{Sg}$ last.year

'I read the book that Dàkóráá wrote last year.'

In fact, the ungrammaticality of (i) is predicted. It reduces to a requirement that the external D must 'bind' the internal head in a relevant sense (Williamson, 1987; Basilico, 1996). If the internal head is also dominated by its own D, it is not possible for it to be further bound by the external determiner. In our structural terms, recall that the determiner takes a DemP as shown in (17b). Thus if the internal head also has $\grave{a}$, the external $\grave{a}$ cannot bind the internal head noun. See also Watanabe (2004) and Hiraiwa (2005) for similar analyses. 


\section{Acknowledgments}

We are grateful to Mark Baker, Guglielmo Cinque, Chris Collins, Tomohiro Fujii, Michael Kenstowicz, Leslie Saxon, Matt Shibatani, and Akira Watanabe, the editors of Lingua, and two anonymous reviewers for insightful comments and/or discussions. This research is partially funded by the Research Grants Council through project No. GRF HKU 740708H for the first author and the Grant-in-Aid for JSPS Fellows No.1710271 for the second author.

\section{References}

Aoun, J., Li, Y.-H.A., 2003. Essays on the Representational and Derivational Nature of Grammar: The Diversity of Wh-Constructions. MIT Press, Cambridge, MA.

Bach, E., 1971. Questions. Linguistic Inquiry 2, 153-166.

Baker, M., 2001. The Atoms of Language: The Mind's Hidden Rules of Grammar. Basic Books, New York, NY.

Basilico, D., 1996. Head positions and internally headed relative clauses. Language 72, 498-532.

Bhatt, R., 2002. The raising analysis of relative clause: evidence from adjectival modification. Natural Language Semantics 10, 43-90.

Bianchi, V., 2000. The raising analysis of relative clauses: A reply to Borsley. Linguistic Inquiry 31, 123-140.

Bianchi, V., 2002. Headed relative clauses in generative syntax, part I \& II. GLOT 197-204, 235-247.

Bodomo, A., 1997. The Structure of Dagaare. CSLI, Stanford, CA.

Bodomo, A., 2000. Dagaare: Languages of The World Materials No. 165. Lincom Europa, Munchen.

Borsley, R.D., 1997. Relative clauses and the theory of phrase structure. Linguistic Inquiry 28, 629-647.

Brame, M. K., 1968. A new analysis of the relative clause: evidence from an interpretive theory. Unpublished Ph.D. dissertation, MIT.

Bresnan, J., 1970. On complementizers: toward a syntactic theory of complementation. Foundations of Language 6, $292-321$.

Cecchetto, C., Donati, C., 2008. Towards a head raising analysis of relative clauses, a paper presented at the 18th Colloquium on Generative Grammar.

Chomsky, N., 1977. On WH-movement. In: Peter Culicover, T.W., Akmajian, A. (Eds.), Formal Syntax. Academic Press, New York, pp. 71-132. Chomsky, N., 1995. The Minimalist Program. MIT Press, Cambridge, MA.

Chomsky, N., 2000. Minimalist inquiries: The framework. In: Martin, R., Michaels, D., Uriagereka, J. (Eds.), Step by Step: Essays on Minimalist Syntax in honor of Howard Lasnik. MIT Press, Cambridge, MA, pp. 89-155.

Chomsky, N., 2004. Beyond explanatory adequacy. In: Belletti, A. (Ed.), Structures and Beyond: The Cartography of Syntactic Structures, vol. 3. Oxford University Press, New York, NY, pp. 104-131.

Cinque, G., 1982. On the theory of relative clauses and markedness. The Linguistic Review 1, 247-296.

Cole, P., 1987. The structure of internally headed relative clauses. Natural Language \& Linguistic Theory 5 (2), $277-302$.

Collins, C., 1994. The factive construction in Kwa. In: Lefebvre, C., (Ed.), Travaux de recherche sur le créole haïtien. Groupe de recherche sur le créole haïtien, Départment de linguistique, Université du Québec à Montréal, Montreal, pp. 31-65.

Culy, C., 1990. The Syntax and Semantics of Internally Headed Relative Clauses. Ph.D. dissertation, Stanford University.

Dakubu, K.M., 1992. Contrast in context: topic, focus and definiteness in Ga. Journal of West African Linguistics XXII, 1-16.

Dakubu, K. M., 2005. Dagaare: Collected Language Notes, vol. 26. Institute of African Studies, Legon, Legon, Ghana.

Gorbet, L., 1977. Headless relatives in the Southwest: Are they related? In: Peranteau, P.M., Levi, J.N., Phares, G.C. (Eds.), The Chicago Which Hunt. CLS, Chicago, pp. 270-278.

Greenberg, J., 1978. How does a language acquire gender markers? In: Universals of Human Language, vol. 3: Word Structure. Stanford University Press, Stanford, CA, pp. 49-81.

Grosu, A., 2002. Strange relatives at the interface of two millennia. GLOT 6 (6), 145-167.

Grosu, A., Landman, F., 1998. Strange relatives of the third kind. Natural Language Semantics 6, 125-170.

Hiraiwa, K., 2005. Dimensions of Symmetry in Syntax: Agreement and Clausal Architecture. Unpublished Ph.D. dissertation, MIT.

Hiraiwa, K., 2008. The head-internal relativization parameter in Gur: D and EPP. In: The Proceedings of the NELS 38. GLSA, Amherst, MA.

Hiraiwa, K., in preparation. Head-internal relative clauses and parameters.

Hiraiwa, K., Bodomo, A., 2008. Object-sharing as symmetric sharing: predicate clefting and serial verbs in Dàgáárè. Natural Language \& Linguistic Theory, 795-832. DOI:10.1007/s11049-008-9056-y. Springer.

Hulsey, S., Sauerland, U., 2006. Sorting out relative clauses. Natural Language Semantics 14, 111-137.

Iatridou, S., Anagnostopoulou, E., Izvorski, R., 2001. Some observations about the form and meaning of the perfect. In: Kentowicz, M. (Ed.), Ken

Hale: A Life in Language. MIT Press, Cambridge, MA, pp. 189-238.

Jackendoff, R., 1972. Semantic Interpretation in Generative Grammar. MIT Press, Cambridge, MA.

Kayne, R., 1994. The Antisymmetry of Syntax. MIT Press, Cambridge, MA.

Kayne, R., 2008. Why isn't this a complementizer?, New York University.

Keenan, E., Comrie, B., 1977. Noun phrase accessibility and universal grammar. Linguistic Inquiry 8, 62-100.

Kendall, M. B., 1976. Selected Problems in Yavapai Syntax: the Verde Valley Dialect. Garland, New York.

Kuno, S., 1973. The Structure of The Japanese Language. MIT Press, Cambridge, MA.

Kuroda, S.-Y., 1992. Japanese Syntax and Semantics: Collected Papers. Kluwer Academic Publishers, Dordrecht.

Lebeaux, D., 1990. Relative clauses, licensing, and the nature of the derivation. In: Carter, J., Dechaine, R.-M., Philip, B., Sherer, T. (Eds.), The Proceedings of the NELS 20. GLSA, Amherst, MA, pp. 318-332. 
Lehmann, C., 1984. Der Relativsatz: Typologie seiner Strukturen. Narr, Tübingen.

Peterson, T.H., 1974. On definite restrictive relatives in Mooré. Journal of West African Linguistics 4 (2), 71-78.

Platzack, C., 2000. A complement-of- $\mathrm{N}^{0}$ account of restrictive and non-restrictive relatives: The case of Swedish. In: Alexiadou, A., Law, P., Meinunger, A., Wilder, C. (Eds.), The Syntax of Relative Clauses. John Benjamins, Amsterdam, pp. 265-308.

Rizzi, L., 1997. The fine structure of the left periphery. In: Haegeman, L. (Ed.), Elements of Grammar: Handbook of Generative Syntax. Kluwer Academic Publishers, Dordrecht, pp. 281-337.

Sag, I., 1997. English relative clauses. Journal of Linguistics 33, 431-483.

Schachter, P., 1973. Focus and relativization. Language 49 (1), 19-46.

Smith, C., 1964. Determiners and relative clauses in a generative grammar of English. Language 40, 37-52.

Stockwell, R., Schachter, P., Partee, B.H., 1973. The Major Syntactic Structures of English. Holt. Rinehart and Winston, New York.

Tellier, C., 1989. Head-internal relatives and parasitic gaps in Mooré. In: Haïk, I., Tuller, L. (Eds.), Current Approaches to African Linguistics, vol. 6. Foris, Dordrecht, pp. 298-318.

Vergnaud, J.-R., 1974. French Relative Clauses. Unpublished Ph.D. dissertation, MIT.

Watanabe, A., 1991. Wh-in-situ, Subjacency, and Chain Formation. MIT Occasional Papers in Linguistics, vol. 2. MITWPL, Cambridge, MA.

Watanabe, A., 2004. Parametrization of quantificational determiners and head-internal relatives. In: Language, Linguistics, 5:1, Academia Sinica, Taiwan, pp. 59-97.

Watanabe, A., 2006. The pied-piper feature. In: Cheng, L., Corver, N. (Eds.), WH-Movement: Moving on. MIT Press, Cambridge, MA, pp. 47-70. Williamson, J., 1987. An indefiniteness restriction for relative clauses in Lakhota. In: Reuland, E., ter Meulen, A.G.B. (Eds.), The Representation of (In)definiteness. MIT Press, Cambridge, MA, pp. 168-190.

Wilson, W., 1963. Relative constructions in Dagbani. Journal of West African Languages 2 (2), 139-144. 